OPEN ACCESS

Edited by:

Nicole Thielens,

UMR5075 Institut de Biologie

Structurale (IBS), France

Reviewed by:

Nick Devoogdt,

Free University of Brussels, Belgium Deborah Fraser,

California State University, United States

*Correspondence: Nick S. Laursen ns/@mbg.au.dk

Specialty section This article was submitted to Molecular Innate Immunity, a section of the journal

Frontiers in Immunology

Received: 15 April 2020 Accepted: 09 June 2020 Published: 17 July 2020

Citation: Laursen NS, Pedersen DV, Gytz H, Zarantonello A, Bernth Jensen JM, Hansen AG, Thiel $S$ and Andersen GR

(2020) Functional and Structural Characterization of a Potent C19 Inhibitor Targeting the Classical Pathway of the Complement System.

Front. Immunol. 11:1504.

doi: 10.3389/fimmu.2020.01504

\section{Functional and Structural Characterization of a Potent C1q Inhibitor Targeting the Classical Pathway of the Complement System}

\author{
Nick S. Laursen ${ }^{1 *}$, Dennis V. Pedersen ${ }^{1}$, Heidi Gytz ${ }^{1}$, Alessandra Zarantonello ${ }^{1}$, \\ Jens Magnus Bernth Jensen ${ }^{2}$, Annette G. Hansen ${ }^{3}$, Steffen Thiel ${ }^{3}$ and \\ Gregers R. Andersen ${ }^{1}$
}

${ }^{1}$ Department of Molecular Biology and Genetics, Center for Structural Biology, Aarhus University, Aarhus, Denmark, ${ }^{2}$ Department of Clinical Immunology, Aarhus University Hospital, Aarhus, Denmark, ${ }^{3}$ Department of Biomedicine, Aarhus University, Aarhus, Denmark

The classical pathway of complement is important for protection against pathogens and in maintaining tissue homeostasis, but excessive or aberrant activation is directly linked to numerous pathologies. We describe the development and in vitro characterization of C1qNb75, a single domain antibody (nanobody) specific for $\mathrm{C} 1 \mathrm{q}$, the pattern recognition molecule of the classical pathway. C1qNb75 binds to the globular head modules of human $\mathrm{C} 1 \mathrm{q}$ with sub-nanomolar affinity and impedes classical pathway mediated hemolysis by $\lg \mathrm{G}$ and $\operatorname{lgM}$. Crystal structure analysis revealed that $\mathrm{C} 1 \mathrm{qNb} 75$ recognizes an epitope primarily located in the C1q B-chain that overlaps with the binding sites of $\operatorname{lgG}$ and IgM. Thus, C1qNb75 competitively prevents C1q from binding to $\lg \mathrm{G}$ and $\operatorname{lgM}$ causing blockade of complement activation by the classical pathway. Overall, C1qNb75 represents a high-affinity nanobody-based inhibitor of IgG- and IgM-mediated activation of the classical pathway and may serve as a valuable reagent in mechanistic and functional studies of complement, and as an efficient inhibitor of complement under conditions of excessive CP activation.

Keywords: complement system, nanobody, antibody, inhibitor, C1q, crystal structure

\section{INTRODUCTION}

The complement system plays an important role in maintaining homeostasis by removal of apoptotic cells and pathogens (1). The classical pathway (CP) of complement is activated by binding of the $\mathrm{C} 1$ complex to a number of ligands, including immunoglobulin $\mathrm{G}(\mathrm{IgG})$ and immunoglobulin $\mathrm{M}(\operatorname{IgM})$ bound to surface antigens or in immune complexes. The $\mathrm{C} 1$ complex consists of the pattern recognition molecule $\mathrm{Clq}$ associated with a tetramer of the proteases $\mathrm{C} 1 \mathrm{r}$ and $\mathrm{C} 1 \mathrm{~s}$. $\mathrm{Clq}$ is a multimeric molecule with six heterotrimeric collagen helices made up by the $\mathrm{A}, \mathrm{B}$, and $\mathrm{C}$-chains (2). The $\mathrm{N}$-terminal collagen regions in the three C1q subunits form heterotrimers that hexamerize to form intact $\mathrm{C} 1 \mathrm{q}$, and these collagen regions also firmly hold $\mathrm{C} 1 \mathrm{r}$ and $\mathrm{C} 1 \mathrm{~s}$ attached. The collagen helices are tightly packed at the $\mathrm{N}$-terminus but diverge toward the $\mathrm{C}$-terminus into six individual collagen stems that end in trimeric C-terminal globular heads (gC1q). Each chain of $\mathrm{gClq}$ adopts a ten-stranded $\beta$-sandwich fold that together form the highly compact spherical structure of $\mathrm{gClq}(2-4)$. 
The $\mathrm{gClq}$ mediates the $\mathrm{Clq}$ interaction with numerous ligands including the Fc-region of antigen-bound $\operatorname{IgG}$ and IgM (5-7). Recognition by $\mathrm{Clq}$ leads to autoactivation of $\mathrm{C} 1 \mathrm{r}$ which cleaves and activates $\mathrm{C} 1 \mathrm{~s}$. Activated $\mathrm{C} 1$ s cleaves $\mathrm{C} 4$ into $\mathrm{C} 4 \mathrm{~b}$, that upon binding of zymogen $\mathrm{C} 2$ forms the $\mathrm{C} 4 \mathrm{bC} 2$ proconvertase complex. This proconvertase is also cleaved by $\mathrm{C} 1$ s resulting in appearance of the $\mathrm{CP}$ C3 convertase $\mathrm{C} 4 \mathrm{bC} 2 \mathrm{a}$ (1). The CP C3 convertase cleaves C3 into C3a and C3b. C3b is deposited at the activator surface and drives the amplification of the alternative pathway (AP) of complement resulting in opsonization and phagocytosis. In contrast, the soluble C3a acts as a modulator of inflammation targeting a range of immune as well as non-immune cells. At sufficiently high $\mathrm{C} 3 \mathrm{~b}$ densities on cells, activation of the terminal pathway (TP) may lead to assembly of the membrane attack complex (MAC) and complement dependent cytotoxicity (CDC) (1).

The best characterized ligands for $\mathrm{C1q}$ are immune complexes containing IgG and IgM. The affinity between $\mathrm{C} 1 \mathrm{q}$ and a single IgG molecule is low (7). However, on a surface, antigen-bound IgGs may oligomerize into large ordered hexameric structures that enable multivalent binding of $\mathrm{C} 1 \mathrm{q}$ and $\mathrm{C} 1$ activation (8). The recognition of IgG involves residues in the B- and C-chains of $\mathrm{gC} 1 \mathrm{q}$, that interact with both $\mathrm{CH} 2$ domains of IgG (9-15). In contrast to IgG, IgM circulates primarily as pentamers and a smaller amount of hexamers. Mutational studies and cryoelectron tomography structures of IgM in complex with $\mathrm{C} 1$ suggest that the binding site of $\mathrm{Clq}$ is located in the IgM C $\mu 3$ domain $(16,17)$ with residues in the $\mathrm{B}$-chain of $\mathrm{gClq}$ being involved in the interaction $(18,19)$.

Initiation of the CP can lead to opsonization, cell lysis and may induce a potent inflammatory response, and as a consequence, undesirable $\mathrm{CP}$ activation can lead to pathology. CP activation can result in allograft rejection following transplantation (20) but can also drive a number of autoantibody mediated diseases including neuromyelitis optica (NMO) $(21,22)$, generalized myasthenia gravis (gMG) $(23,24)$, and cold agglutinin disease (CAD) (25). Autoantibodies can bind to self-surfaces or be deposited as immune complexes and activate the $\mathrm{CP}$ resulting in tissue damage and inflammation. In $\mathrm{NMO}$ and $\mathrm{gMG}$, IgG autoantibodies against aquaporin-4 (22) and acetylcholine receptors, respectively, activate the $\mathrm{CP}$ which leads to $\mathrm{CDC}$ mediated injury to astrocytes in the case of NMO (26) or at the neuromuscular junction in gMG (24). CAD is usually caused by IgM autoantibodies against the "I" antigen on erythrocytes (25) and results in C3 deposition on erythrocytes and extravascular hemolysis by macrophages of the reticuloendothelial system in the liver $(27,28)$. Inhibition of $\mathrm{CP}$ with an anti-C1s $\mathrm{mAb}$ (Sutimlimab) abrogated extravascular hemolysis in CAD patients supporting an important role of complement as a pathogenic factor in CAD and the CP as a therapeutic target (29).

With the realization that complement is involved in numerous disease states, therapeutic strategies to modulate specific complement components are gaining increased attention (30). Despite the recognized contributions from CP and the related lectin pathway (LP) to pathogenesis, the AP and TP have primarily been targeted. Here, we present a C1q specific nanobody (C1qNb75) that inhibits $\mathrm{CP}$ activation driven by $\mathrm{IgG}$ and IgM. Nanobodies are single domain antibodies derived from the variable domain of camelid heavy-chain only antibodies. We demonstrate that $\mathrm{C} 1 \mathrm{qNb} 75$ binds with sub-nanomolar affinity to human gC1q. It directly blocks C1q's interaction with IgG, and prevents activation of complement via IgG and IgM ligands, and antibody-mediated hemolysis.

\section{RESULTS}

\section{Nanobody Generation and Characterization}

To isolate nanobodies ( $\mathrm{Nbs}$ ) against $\mathrm{Clq}$ we immunized a llama with a mixture of human $\mathrm{Clq}$ and gC1q. Peripheral blood mononuclear cells were isolated and a phage display library presenting the Nbs as fusion proteins fused to the PIII phage coat protein, was generated. After two rounds of in vitro selection, we obtained a number of clones, which were subsequently cloned into a bacterial expression vector, expressed and purified. After initial characterization of the nanobodies's ability to inhibit IgG mediated complement activation (Figure S1A) we identified $\mathrm{C} 1 \mathrm{qNb} 75$ as a potent $\mathrm{CP}$ inhibitor and we decided to further characterize this $\mathrm{Nb}$. Binding of recombinant $\mathrm{C} 1 \mathrm{qNb} 75$ to $\mathrm{C1q}$ was first evaluated by a sandwich-type solid-phase immunoassay using $\mathrm{C} 1 \mathrm{qNb} 75$ coated in microtiter wells at different concentrations and purified $\mathrm{C1q}$ or normal human serum (NHS) as a source of $\mathrm{Clq}$ (Figure 1A). Immobilized $\mathrm{C} 1 \mathrm{qNb} 75$ captured both purified $\mathrm{C} 1 \mathrm{q}$ and $\mathrm{C} 1 \mathrm{q}$ from NHS in a dose-dependent manner. The interaction was further characterized using bio-layer interferometry (BLI). We coupled $\mathrm{C} 1 \mathrm{qNb} 75$ to amine reactive sensors and the interaction was assayed using $\mathrm{Clq}$ purified from human plasma (Figure 1B). Increasing signal was observed for increasing concentrations of C1q. As C1q is a homo-hexamer, and one molecule of C1q may bind up to six $\mathrm{Nb}$ molecules simultaneously, we did not attempt to calculate the binding constants. Instead, we used BLI to evaluate binding of immobilized $\mathrm{C} 1 \mathrm{qNb} 75$ to monomeric singlechain recombinant gC1q (Figure 1C). The $\mathrm{Nb}$ bound gC1q with very high affinity $\left(\mathrm{K}_{\mathrm{D}}=0.3 \mathrm{nM}\right)$ and an off-rate of $1.7 \times 10^{-4} \mathrm{~s}^{-1}$ corresponding to $\mathrm{t}_{1 / 2}=4.1 \times 10^{3} \mathrm{~s}$ for a first-order dissociation of the monomeric interaction. Comparison of the dissociation phases for $\mathrm{C} 1 \mathrm{q}$ and $\mathrm{gCl} \mathrm{q}$ confirms that $\mathrm{C} 1 \mathrm{q}$ binds with avidity to immobilized $\mathrm{C} 1 \mathrm{qNb} 75$ since the $\mathrm{C} 1 \mathrm{q}$ dissociation is characterized by an extremely slow dissociation phase as compared to the monovalent interaction (Figures 1B,C).

\section{C1qNb75 Blocks Binding of C1q to IgG}

The $\mathrm{CP}$ can be activated by binding of $\mathrm{C} 1 \mathrm{q}$ to immune complexes containing complement activating antibodies. We assayed the ability of $\mathrm{C} 1 \mathrm{q}$ in NHS to bind to surface immobilized human IgG in the presence of increasing concentrations of $\mathrm{C} 1 \mathrm{qNb} 75$ with a solid-phase immunoassay (Figure 2A). Human IgG was immobilized in microtiter wells and incubated with $0.2 \%$ NHS in the presence of variable concentrations of $\mathrm{C} 1 \mathrm{qNb} 75$, control $\mathrm{Nb}$ or IgG anti-C1q. This was followed by detection of bound C1q with biotin labeled anti-C1q antibody. C1qNb75 clearly inhibited binding of $\mathrm{C} 1 \mathrm{q}$ in a concentration dependent manner 


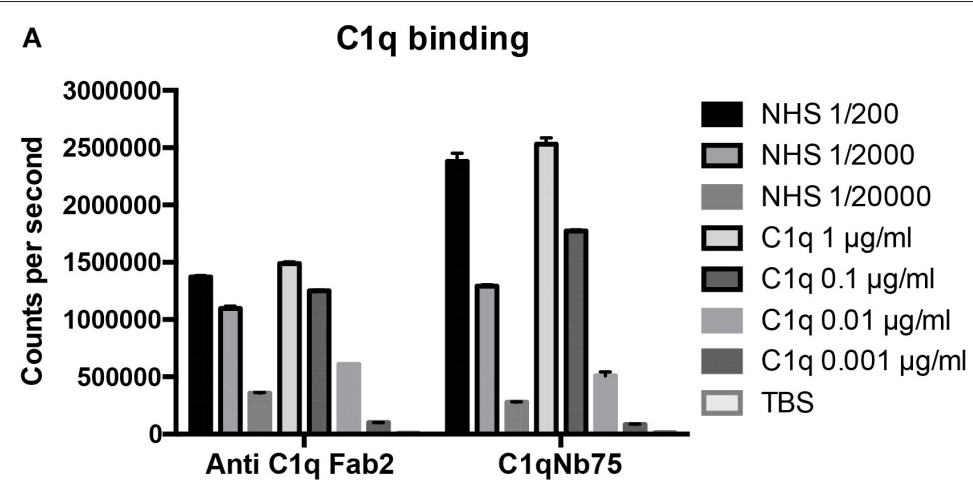

B

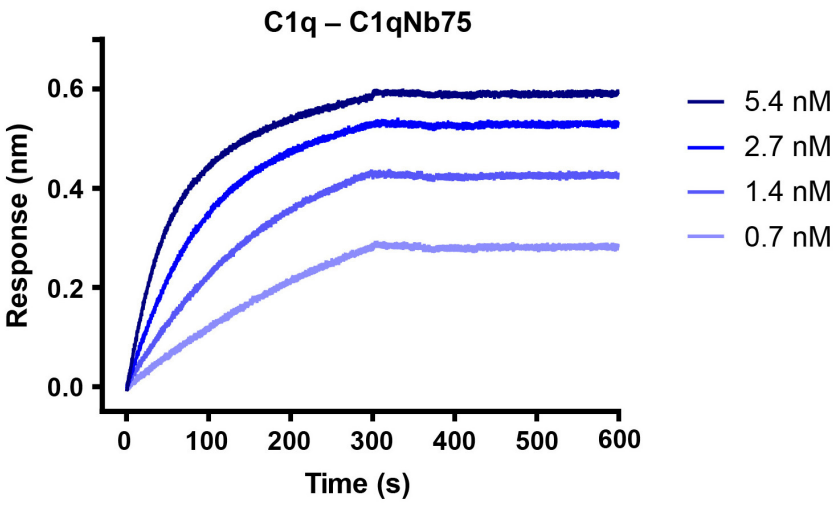

C gC1q-C1qNb75

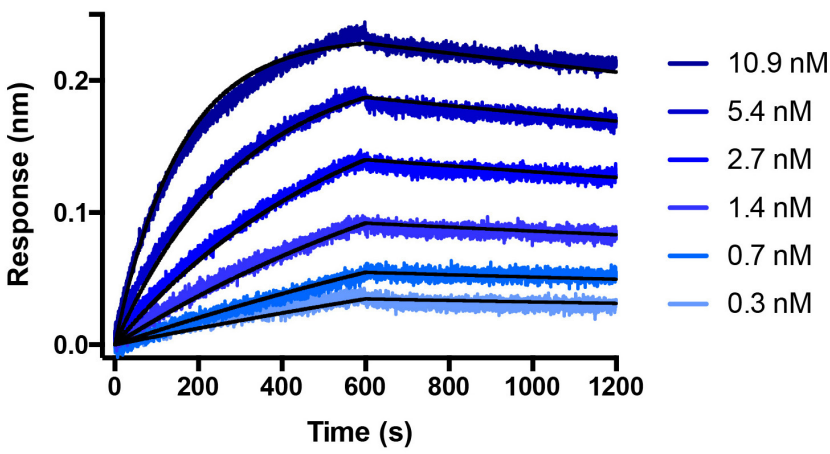

$K_{\mathrm{D}} 2.9 \times 10^{-10} \mathrm{M}$ $k_{\text {on }} 5.8 \times 10^{5} \mathrm{M}^{-1} \mathrm{~s}^{-1}$

$k_{\text {off }} 1.7 \times 10^{-4} \mathrm{~s}^{-1}$

FIGURE 1 | C1qNb75 binds with high affinity to human C1q. (A) Solid-phase immunoassay (TRIFMA) with anti-C1q Fab2 or C1qNb75 coated in microtiter wells. The binding of purified C1q or C1q in NHS is measured. The signal is given as counts per second after measurement by time-resolved fluorometry. Shown are mean and SD. (B) Bio-layer interferometry (BLI) measurement of the interaction between purified C1q in solution and immobilized C1qNb75. (C) As in previous panel but showing the interaction between recombinant gC1q and immobilized C1qNb75 with calculated $\mathrm{k}_{\mathrm{on}}, \mathrm{K}_{\mathrm{off}}$, and $\mathrm{K}_{\mathrm{D}}$. The Experimental data (blue curves) was globally fitted to a 1:1 binding model (black curves).

like the anti-C1q IgG, whereas no inhibition was observed with the control $\mathrm{Nb}$.

We next addressed if $\mathrm{C} 1 \mathrm{qNb} 75$ inhibited C1q docking to IgG antibodies bound on antigens. To do this, we used human antibody deficient serum (ADS) as source of C1q, affinity purified human IgG antibodies recognizing terminal galactose$\alpha$-1,3-galactose (IgG anti- $\alpha \mathrm{Gal}$ ) and pig red blood cells (RBCs), which express the relevant carbohydrate structure. These RBCs present $\sim 6 \times 10^{4}$ terminal galactose- $\alpha$-1,3-galactose residues per cell (31) and efficiently bind the affinity purified antibody preparation (32). Using flow cytometry, we found that increasing concentrations of $\mathrm{C} 1 \mathrm{qNb} 75$ caused decreasing $\mathrm{C} 1 \mathrm{q}$ deposition on pig RBCs (Figure 2B), supporting blockage of C1q docking on antigen-bound antibodies by the $\mathrm{Nb}$. In accordance with 


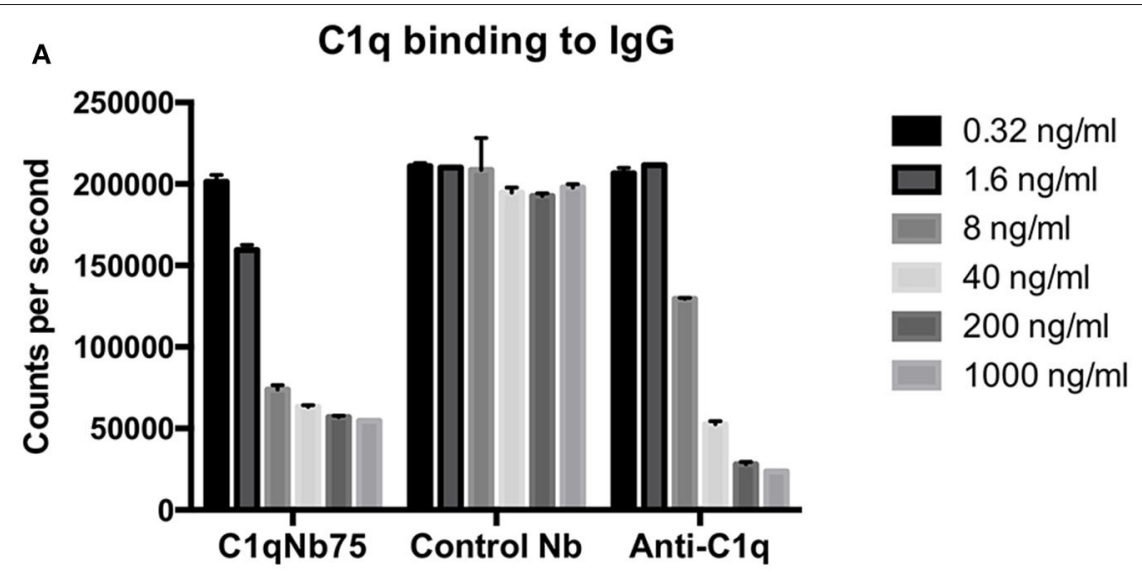

$\mathbf{B}$
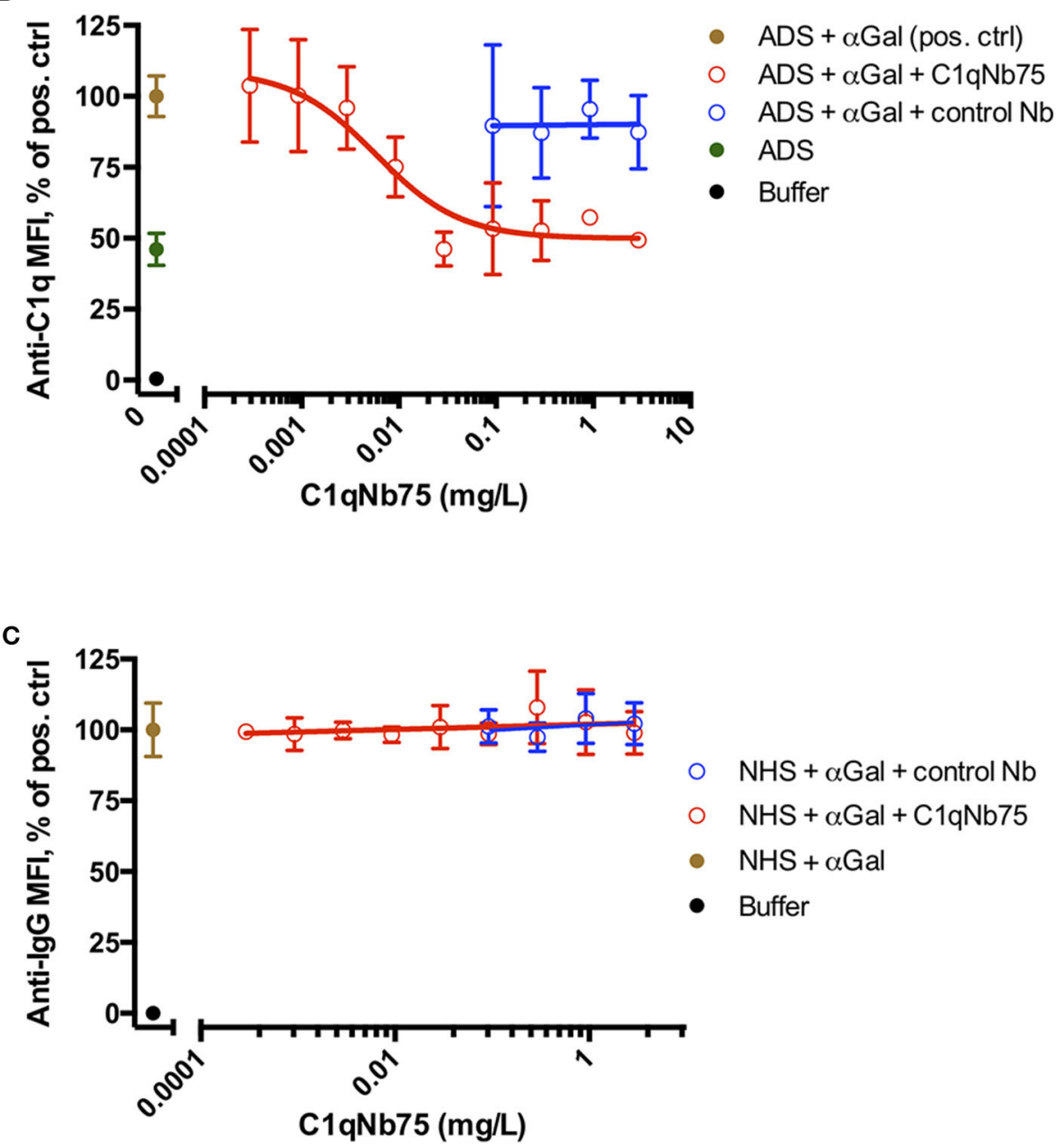

FIGURE 2 | C1qNb75 interferes with binding of C1q to surface bound IgG. (A) Binding of C1q to IgG in microtiter wells in the presence of the indicated contractions of $\mathrm{C} 1 \mathrm{qNb} 75$, control $\mathrm{Nb}$ or anti-C1q antibody. (B) Binding of $\mathrm{C} 1 \mathrm{q}$ (in ADS) to antibody sensitized pig red blood cells in the presence of $\mathrm{C} 1 \mathrm{qNb} 75$ or control Nb. $\mathrm{C} 1 \mathrm{q}$ binding was detected by flow cytometry using a polyclonal fluorescently labeled anti-C1q antibody and plotted as \% of mean fluorescence intensity (MFI) of a positive control with SD. Results are representative of two independent experiments. (C) Same experiments as in panel (B), but where binding of IgG was measured with flow cytometry using fluorescently labeled anti-lgG. 

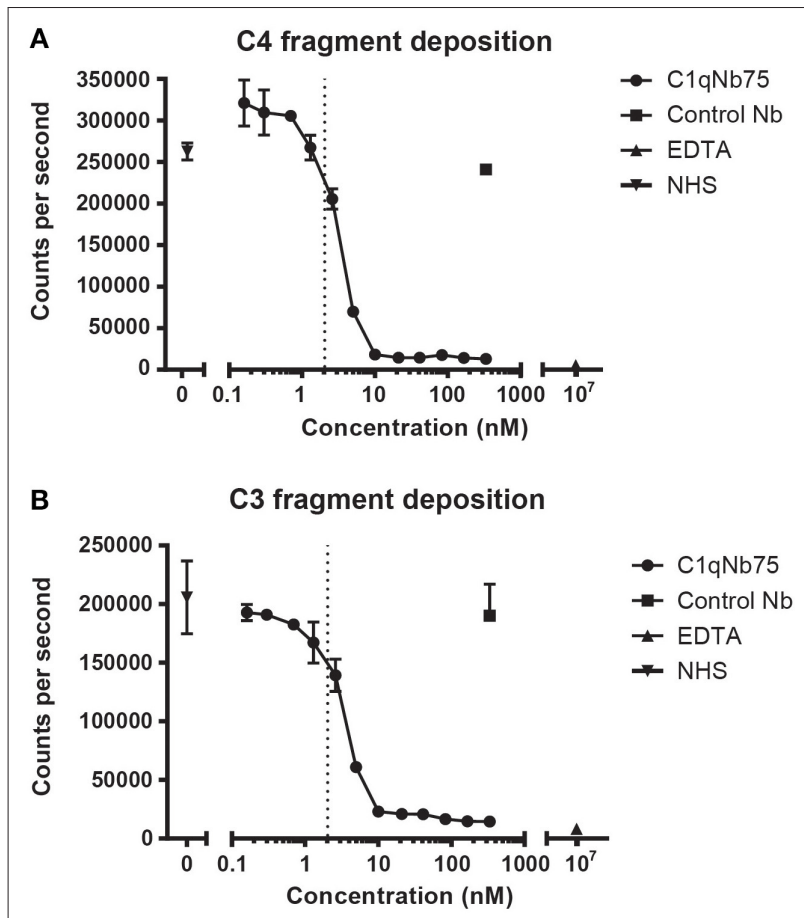

C IgG antibody mediated hemolysis

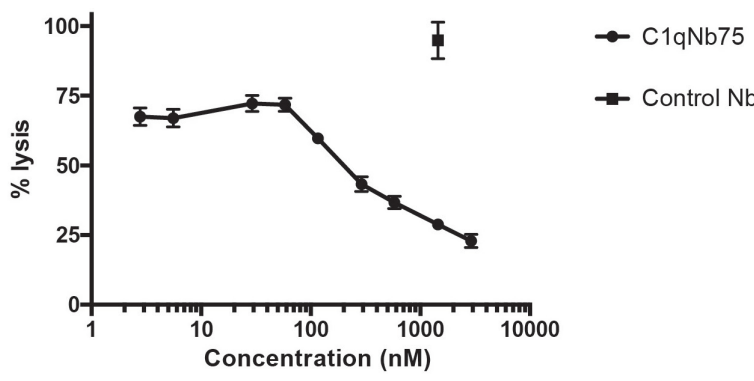

D IgM antibody mediated hemolysis

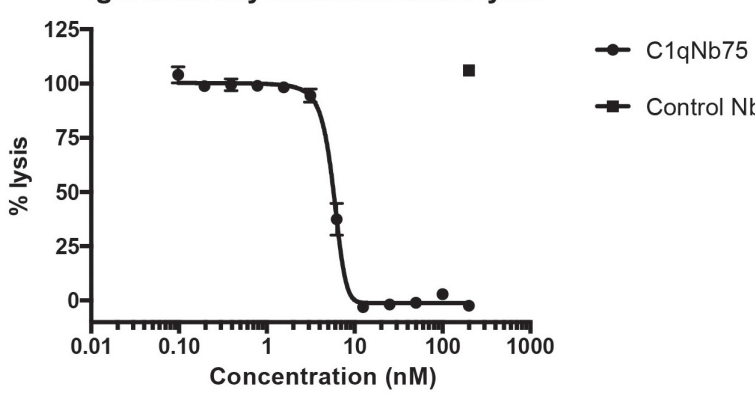

FIGURE 3 | C19Nb75 inhibits IgG and IgM mediated activation of the classical pathway and hemolysis. (A) Deposition of $\mathrm{C} 4$ fragments on IgG coated surface from $0.2 \% \mathrm{NHS}$ in the presence of increasing concentrations of C1qNb75, control Nb $(333 \mathrm{nM})$ or EDTA $(10 \mu \mathrm{M})$. Shown are mean and SD of two independent experiments. The dotted line indicates the calculated $\mathrm{Nb}$ concentration resulting in a 1:1 binding to gC1q. (B) As in panel A, but measuring C3 fragment deposition. (C) Hemolysis of sheep RBCs sensitized with $\operatorname{lgG}$ in the presence of increasing concentrations of $\mathrm{C} 1 \mathrm{gNb} 75$, control $\mathrm{Nb}$ or EDTA. Data are plotted as \% lysis where 100\% lysis is incubation of RBCs with water. Results are representative of two similar experiments.

(Continued)
FIGURE 3 | Shown are mean and SD. (D) Hemolysis of sheep RBCs sensitized with IgM in the presence of increasing concentrations of $\mathrm{C} 1 \mathrm{qNb} 75$, control Nb or EDTA. Data are plotted as \% lysis where 100\% lysis is incubation of RBCs with water. Results are representative of three independent experiments. Shown are mean and SD.

the $\mathrm{K}_{\mathrm{D}}$ value observed by BLI, the inhibition curve had an inflection point below a C1qNb75 concentration of $0.01 \mathrm{mg} / \mathrm{L}$, corresponding to a nanobody concentration of $0.7 \mathrm{nM}$. A control $\mathrm{Nb}$ of irrelevant specificity at similar concentrations did not displace $\mathrm{Clq}$ from the RBCs (Figure 2B). Moreover, neither $\mathrm{C} 1 \mathrm{qNb} 75$ nor the control $\mathrm{Nb}$ influenced antibody binding on pig RBCs in NHS (Figure 2C), in accordance with selective blockade of C1q's ability to dock on immunoglobulins. Interestingly, even at high $\mathrm{Nb}$ concentrations, $\mathrm{Clq}$ binding was not inhibited to a level comparable to that of buffer alone, but plateaued at a level similar to that of ADS alone (Figure 2B). This suggests that $\mathrm{Clq}$ may bind some ligand on pig $\mathrm{RBCs}$ even in the presence of $\mathrm{ClqNb} 75$. Whether $\mathrm{C} 1 \mathrm{q}$ binds pig $\mathrm{RBCs}$ through a site in the $\mathrm{gClq}$ domain not concealed by $\mathrm{C} 1 \mathrm{qNb} 75$ or via its collagen tail needs further investigation. Overall these experiments demonstrated that $\mathrm{C1qNb} 75$ blocks $\mathrm{C} 1 \mathrm{q}$ docking on aggregated IgG and IgG bound to antigens.

\section{Inhibition of Antibody Mediated CP Activation and Hemolysis}

The classical pathway is activated by both IgG and IgM, and we first evaluated the effect of $\mathrm{ClqNb} 75$ on CP activation by IgG. $\mathrm{CP}$ activation was assayed by measuring $\mathrm{C} 4$ and $\mathrm{C} 3$ fragment deposition in IgG coated microtiter wells with NHS as a source of complement. C1qNb75 potently inhibited $\mathrm{C} 4$ deposition in a concentration-dependent manner (Figure 3A). Consistent with $\mathrm{C} 3$ being downstream of $\mathrm{C} 4$ in the $\mathrm{CP}, \mathrm{C} 1 \mathrm{qNb} 75$ also inhibited C3 deposition (Figure 3B). No C4 and C3 deposition occurred when divalent metal ions were chelated from the NHS with $10 \mathrm{mM}$ EDTA. The presence of control $\mathrm{Nb}(333 \mathrm{nM})$ had no effect on $\mathrm{C} 4$ and $\mathrm{C} 3$ deposition compared to incubation with NHS only (Figures 3A,B). A sharp drop in C3 and C4 deposition was observed at a $\mathrm{C} 1 \mathrm{qNb} 75$ concentration of $2-4 \mathrm{nM}$, roughly corresponding to six times the calculated concentration of $\mathrm{Clq}$ in the assay assuming a serum concentration of $\mathrm{Clq}$ at $170 \mathrm{nM}$ $\left(2.04 \mathrm{nM}\right.$, dotted line in Figures 3A,B). If the $\mathrm{K}_{\mathrm{D}}=0.29 \mathrm{nM}$ observed by BLI is applicable in this serum-based experiment, and binding of the nanobody to its six binding sites on $\mathrm{C} 1 \mathrm{q}$ is non-cooperative, it appears that $\mathrm{C} 1 \mathrm{qNb} 75$ must bind at least four gC1q's to efficiently inhibit IgG mediated CP activation.

Depending on the level of complement regulation, activation of CP may result in TP activation and MAC formation. As an indirect assessment of MAC formation in the presence of $\mathrm{ClqNb} 75$, we performed hemolysis assays with IgG antibody sensitized sheep RBCs and NHS as source of complement. C1qNb75 blocked IgG mediated hemolysis in a concentrationdependent manner while no effect was observed when incubating with a control $\mathrm{Nb}$ (Figure 3C). We next asked whether C1qNb75 could also inhibit hemolysis due to $\mathrm{CP}$ activation driven by IgM. 
Though IgG and IgM share homology and are both ligands for C1q, C1q recognizes IgG and $\operatorname{IgM}$ differently $(9,17,19)$. Thus, C1qNb75 could potentially block $\mathrm{C} 1 \mathrm{q}$ binding to IgG without affecting binding to IgM. To investigate the influence of the nanobody on IgM mediated CP activation, IgM-sensitized sheep RBCs were incubated with NHS in the presence of $\mathrm{C} 1 \mathrm{qNb} 75$ or control Nb and hemolysis was measured (Figure 3D). C1qNb75 strongly inhibited IgM mediated hemolysis in a concentrationdependent manner with a half maximal inhibitory concentration (IC50) of $5.8 \mathrm{nM}$. Addition of control $\mathrm{Nb}$ of irrelevant specificity did not inhibit hemolysis (Figure 3D). To investigate if C1qNb75 binding to $\mathrm{Clq}$ itself can activate complement, we measured C5a generation in NHS after addition of the $\mathrm{Nb}$. As shown in Figure S1B, increasing $\mathrm{C} 1 \mathrm{qNb} 75$ concentrations had no effect on $\mathrm{C} 5 \mathrm{a}$ generation. Collectively the data show that $\mathrm{C} 1 \mathrm{qNb} 75$ inhibits IgG and IgM mediated complement activation and CDC as assayed by sheep RBC lysis.

\section{C1qNb75 Sterically Prevents the Interaction Between C1q and Antibodies}

To unravel the molecular details of the interaction between $\mathrm{C} 1 \mathrm{qNb} 75$ and $\mathrm{gClq}$ we determined the crystal structure of $\mathrm{C} 1 \mathrm{qNb} 75$ in complex with $\mathrm{gClq}$ at $2.2 \AA$ resolution (Figure 4A and Table S1). Clear electron density was observed for the vast majority of residues in $\mathrm{gClq}$ and $\mathrm{ClqNb} 75$ (Figure 4B) which allowed us to model the intermolecular interface with high confidence. PISA analysis (33) revealed an epitope with an area of $740 \AA^{2}$ on C1q, which is in the low end for such complexes, whereas the observed shape complementarity of 0.74 is in the average range (34). In the crystal structure, there are two complexes in the asymmetric unit with the two gC1q copies being almost identical. Minor differences observed in two loops of the $\mathrm{Clq} \mathrm{A}$-chain are likely caused by crystal packing, and these loops are located far from the C1qNb75 epitope. Superposition of the complex with the structure of single-chain gC1q (PDB ID: $5 \mathrm{HKJ}$ ) reveals no major conformational changes in $\mathrm{Clq}$ upon $\mathrm{Nb}$ binding (Figure S1C) suggesting that conformational changes in gC1q induced upon nanobody binding do not contribute to the inhibitory mechanism of $\mathrm{C} 1 \mathrm{qNb} 75$.

$\mathrm{C} 1 \mathrm{qNb} 75$ binds to the side of $\mathrm{gClq}$ and is primarily contacting residues in the $\mathrm{B}$-chain of $\mathrm{C} 1 \mathrm{q}$ supplemented with few contacts to the $\mathrm{C}$-chain. The paratope is made up of residues from all three CDR regions of C1qNb75. In CDR1, Asn32 forms hydrogen bonds with Asn121B (letter after residue number indicates C1q chain, mature numbering of $\mathrm{C1q}$ is used) (Figure 4C). CDR2 residues Thr53 and Gly55 form hydrogen bonds with $\mathrm{C} 1 \mathrm{q}$ residue Glu116B next to Arg114B, which are both involved in the interaction between C1q and IgG (9) (Figure 4D). Asp75 in the $\mathrm{Nb}$ framework region 3 forms a salt bridge with $\mathrm{C} 1 \mathrm{q}$ Arg129B, which is also involved in the interaction with IgG (9) (Figures 4D, 5B). A hydrophobic patch on CDR3 formed by residues Pro102, Pro103, Trp105, Pro106 protrudes from the $\beta$-sandwich immunoglobulin fold and is inserted in a $\mathrm{Clq}$ cavity delimited by the C1q-B chain loop carrying Glu209B, and the loop carrying Thr102B (Figure 4E). The latter residue is close in sequence to Arg108B and Arg109B, known to mediate interactions with pentraxin 3 and IgM (18). The cavity is likely shielded from the solvent due to proximity of C1qNb75 Arg108 to Glu209B on one side, and the presence of gC1q Arg156C on the other side (Figure 4E). Hydrogen bonds are formed between Pro103 and His117B, and from Gly104 to Val161C and Thr100B. In addition, there are multiple water molecules bridging $\mathrm{C} 1 \mathrm{qNb} 75$ with gC1q. Sequence alignment with mouse C1q B-chain explains the absence of mouse cross reactivity (Figure S2A). The most prominent amino acid difference is at position 117 , where the histidine is replaced by a lysine in mouse C1q B, introducing a positively charged and much larger side chain, which likely disrupts the hydrophobic pocket housing Trp105 in human C1q (Figure S2B).

As demonstrated in Figures 2, 3, C1qNb75 potently inhibits $\mathrm{C} 1 \mathrm{q}$ binding to $\mathrm{IgG}$ and $\mathrm{IgM}$. gC1q binds to the $\mathrm{CH} 2$ domains of IgG near the Fab-Fc hinge $(10,11,15)$ using residues located in the B- and C-chains of C1q (9, 12-14). To analyze how C1qNb75 prevents $\mathrm{C} 1 \mathrm{q}$ binding to IgG, we superimposed our structure on that of IgG-Fc bound to gC1q (9) (Figure 5A). This structural comparison reveals that $\mathrm{C} 1 \mathrm{qNb} 75$ blocks binding of $\mathrm{C} 1 \mathrm{q}$ to $\mathrm{IgG}$ by steric hindrance, restraining access to critical $\mathrm{C} 1 \mathrm{q} \mathrm{B}$-chain residues important for recognition of one $\mathrm{CH} 2$ domain of $\mathrm{IgG}$ Fc. (Figure 5B). In contrast, $\mathrm{C} 1 \mathrm{qNb} 75$ does not directly block the area on $\mathrm{C} 1 \mathrm{q}$ involved in binding to the second $\mathrm{CH} 2$ domain of IgG Fc.

With respect to IgM binding, $\mathrm{C} 1 \mathrm{q}$ is suggested to interact with the IgM-Fc C $\mu 3$ domains using residues Arg108B, Arg109B, Arg150B, and Phe178B (17). To examine how C1qNb75 prevents $\mathrm{Clq}$ binding to IgM we first generated an atomic model for $\mathrm{C} 1$ bound to $\operatorname{IgM}$ and $\mathrm{C} 4 \mathrm{~b}$ by fitting known structures into a deposited 3D cryo-electron tomography reconstruction (EMDB-4878 and Table S2) (17), and subsequently aligned the $\mathrm{C} 1 \mathrm{qNb} 75-\mathrm{gC} 1 \mathrm{q}$ complex structure to this model. In this model, C1qNb75 exerts extensive steric clashes with the IgM $\mathrm{C} \mu 3$ domains (Figure 5C). Collectively, the C1qNb75-gC1q complex structure and the structural comparisons demonstrate that $\mathrm{C} 1 \mathrm{qNb} 75$ binds an epitope on $\mathrm{C1q}$ directly involved in recognition of both IgG and IgM and explains how C1qNb75 inhibits complement activation.

\section{DISCUSSION}

$\mathrm{C} 1 \mathrm{q}$ is the pattern recognition molecule of the $\mathrm{C} 1$ complex that initiates the $\mathrm{CP}$ of the complement cascade. Recognition of a plethora of molecular patterns by $\mathrm{Clq}$ induces $\mathrm{C} 1 \mathrm{r}$ and $\mathrm{C} 1$ s activation resulting in $\mathrm{C} 4$ cleavage and assembly of the $\mathrm{CP}$ C3 convertase (35-37). Structural and functional studies have provided information on how $\mathrm{C} 1 \mathrm{q}$ recognizes the $\mathrm{Fc}$-fragments of $\operatorname{IgG}$ and $\operatorname{IgM}(9,10,14,16-19,38)$. gC1q binds a distinct site in each of the two $\mathrm{CH} 2$ domains of IgG1. One binding site consists of the area around loop FG of $\mathrm{CH} 2$ that interacts with $\mathrm{C} 1 \mathrm{q}-\mathrm{B}$ chain residue Phe178B and C1q-C residue Asp195C. The other site is formed by loop $\mathrm{BC}$ and loop $\mathrm{DE}$ of the second $\mathrm{CH} 2$ domain proposed to interact with C1q-B residues Arg114B and Arg129B. Our structural data shows that $\mathrm{C} 1 \mathrm{qNb} 75$ binds to an epitope on gC1q that overlaps with the binding site of IgG Fc $\mathrm{CH} 2$ and thus 

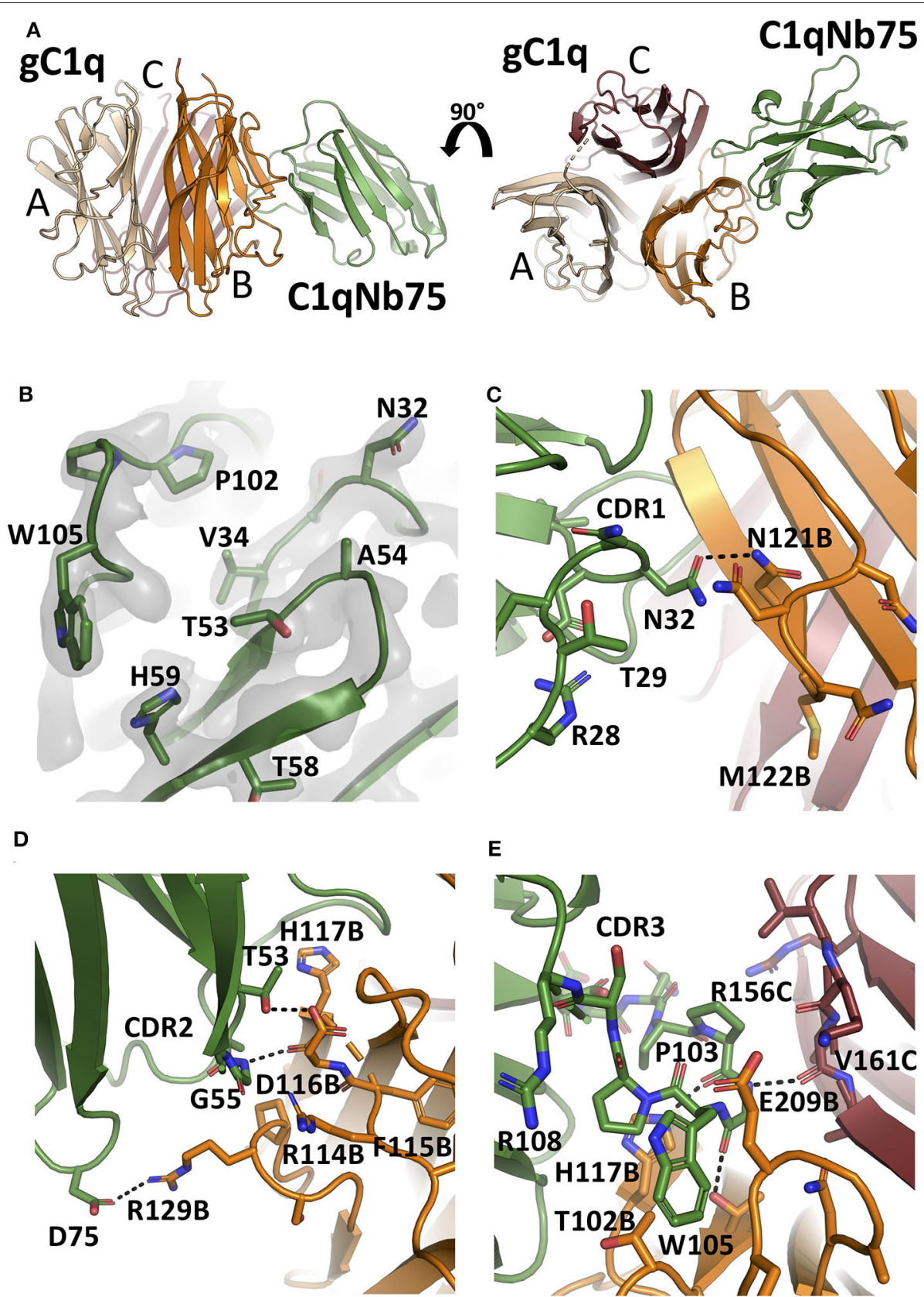

E

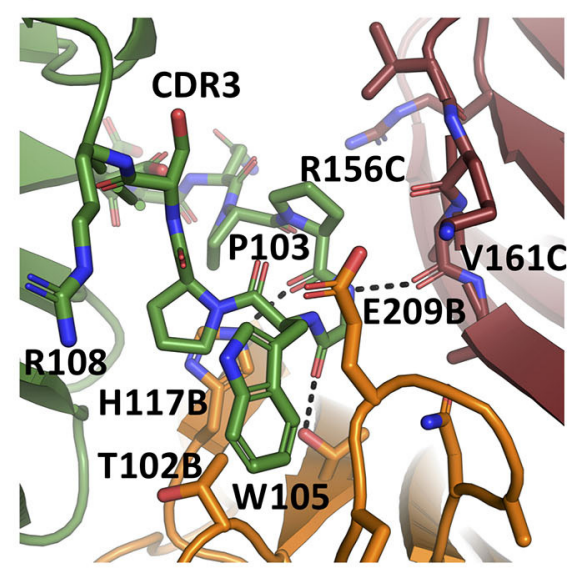

FIGURE 4 | The crystal structure of the gC1q-C1qNb75 complex reveals the epitope. (A) Side view (left) and top view (right) of the gC1q-C1qNb75 complex. The different subunits of $\mathrm{gC1} 1 \mathrm{q}$ are colored in wheat (A-chain), orange (B-chain) and brown (C-chain) whereas $\mathrm{C} 1 \mathrm{gNb} 75$ is displayed in green. (B) Omit $2 \mathrm{mF}_{\mathrm{O}}-\mathrm{DF}_{\mathrm{C}}$ electron density map contoured at $1.2 \sigma$ around the three CDRs. Residues shown with side chains in sticks were omitted for map calculation. (C-E) The interface between gC1q and C1qNb75 with selected residues shown in sticks. (C) CDR1 contacts, (D) CDR2 contacts, (E) CDR3 contacts. Hydrogen bonds are shown with black dashes. The gC1q residues are labeled with their chain identifier as suffix.

blocks docking of $\mathrm{C1q}$ onto IgG. Likewise, our model suggest that $\mathrm{C} 1 \mathrm{qNb} 75$ prevents binding of $\mathrm{Clq}$ to antigen-bound IgM by steric hindrance restraining access to residues on $\mathrm{gClq}$ which are involved in the interaction between $\mathrm{gClq}$ and $\operatorname{IgM} \mathrm{C} \mu 3$.

Our functional data show that $\mathrm{C} 1 \mathrm{qNb} 75$ is a potent inhibitor of antibody-mediated CP activation. Thus, C1qNb75 could represent an initial candidate molecule for further development of a therapeutic agent for treatment of autoantibody-mediated conditions, like CAD, NMO, and gMG, where complement contributes to disease pathogenesis. Targeting complement at the site of $\mathrm{C} 1$ activation would inhibit MAC-induced membrane damage, but also $\mathrm{C} 3 \mathrm{~b}$ deposition and associated effects. In the case of CAD this includes C3b mediated extravascular hemolysis. However, complement also plays a role in stimulating adaptive 

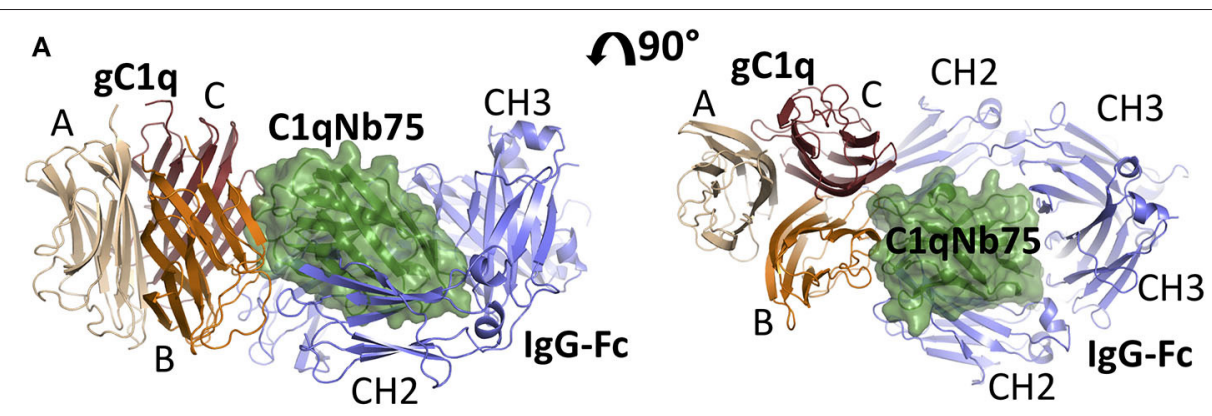

B
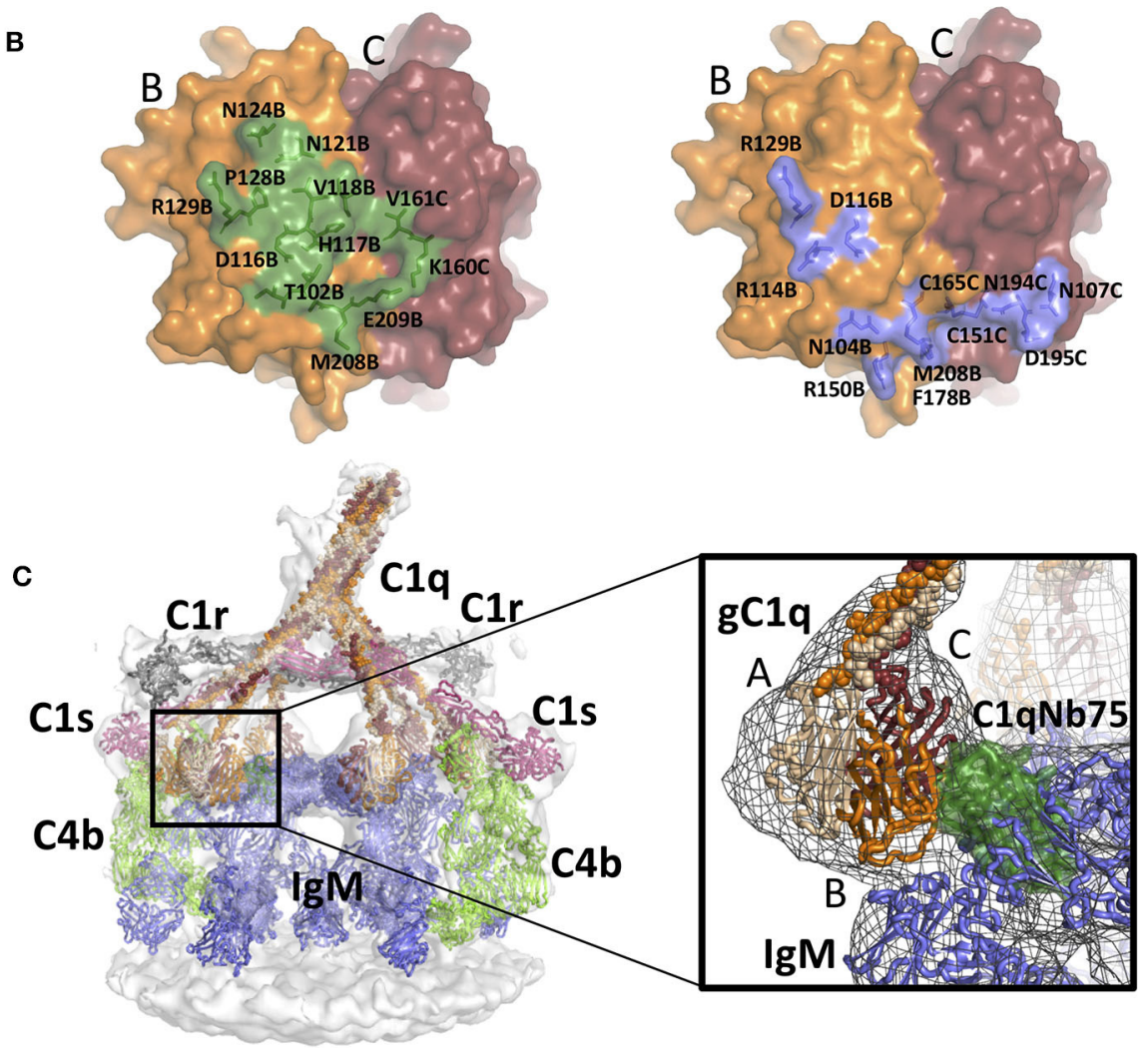

FIGURE 5 | Comparison of the gC1q-C1qNb75 complex with models of IgG FC-gC1q and C1-lgM-C4b explains the inhibition of the CP. (A) Alignment of the crystal structure of the gC1q-C1qNb75 complex with the cryo-EM structure of IgG Fc in complex with gC1q (PDBID: 6FCZ). The gC1q-C1qNb75 is colored as in Figure 4 and IgG-Fc is shown in blue. Similar to Figure 4A, side view (left) and top view (right) are shown. A massive clash between C1gNb75 and lgG Fc is observed. (B) The $\mathrm{C} 1 \mathrm{qNb} 75$ epitope overlaps with gC1q residues involved in IgG contacts. Left: epitope of C1qNb75 on gC1q with residues involved in the interaction shown as sticks and in green. Right: $\mathrm{gC1q}$ residues involved in the interaction with IgG-Fc are shown in sticks and colored blue. (C) Model of the C1-IgM-C4b complex and comparison with the structure of gC1q-C1qNb75. Left: Overview of the entire C1-IgM-C4b complex, right: close up view of the steric overlap of C19Nb75 with IgM Fc. The C4b is colored light green, C1r gray, C1s purple, IgM blue, whereas C1qNb75 and C1q chains are colored as in (A). The 3D reconstruction is displayed as a transparent surface in the overview (left) and as a mesh in the close-up (right).

immunity. Antigens coated with deposited C3 fragments (e.g., membrane fragments with iC3b) can lower the threshold for Bcell activation via complement receptor 2 (CR2) and also increase the time antigens are presented by CR2-expressing follicular dendritic cells to B-cells (39-41). Thus, while the immediate injury in gMG and NMO is caused by CDC, complement, through $\mathrm{iC} 3 \mathrm{~b}$, may also indirectly augment the generation of new autoantibodies and exacerbate the disease on a longer term.
Since the $\mathrm{Clq}$ has a role both in pathogen clearance and in tissue homeostasis by facilitating clearance of apoptotic cells through phagocytosis, long term systemic C1q inhibition needs to be carefully evaluated (42). Genetic deficiencies in $\mathrm{CP}$ components $\mathrm{C} 1 \mathrm{q}, \mathrm{C} 4$ and $\mathrm{C} 2$ strongly associate with the autoimmune disease systemic lupus erythematosus (SLE) (43), that may be caused by the failure of macrophages to phagocytose apoptotic cells (44). However, no adverse effects were observed 
by administration of a C1s specific antibody (sutimlimab) for 2.5 years (29) suggesting that longer term blockade of the CP is safe. In this respect, it is also important to consider that there are functions of $\mathrm{Clq}$ for which the activity of $\mathrm{C} 1 \mathrm{~s}$ and $\mathrm{CP}$ activation appears not to be required (45) but may be influenced by a C1q specific antibody like $\mathrm{C} 1 \mathrm{qNb} 75$ or the $\mathrm{IgG} 4 / \mathrm{Fab}$ ANX005/ANX007 (46).

C1qNb75 does not bind to mouse C1q (data not shown). This prevents application of the $\mathrm{C} 1 \mathrm{qNb} 75$ in murine animal models of complement associated pathogenesis unless mouse $\mathrm{C} 1 \mathrm{q}$ is fully or partially replaced by human $\mathrm{Clq}$ as described in (47). Sequence alignment of the gC1q epitope from common model animals (Figure S2A) suggests that C1qNb75 can be useful in non-murine animal models including primate models of delayed graft function (48) and a pig model of ischemiareperfusion injury (49). Thus, C1qNb75 may be a valuable tool for assessing the contribution of CP-mediated complement activation to diseases driven by allo- and autoantibodies, but also to evaluate complements contribution to the efficacy of therapeutic antibodies.

The biological functions of $\mathrm{Clq}$ extend beyond activation of the classical pathway by immunoglobulins and reach the contexts of tumor growth, neurobiology, pregnancy, hemostasis and immune tolerance as reviewed in (5). Although there are patterns like apoE that are reported to bind $\mathrm{C} 1 \mathrm{q}$ via other sites than gClq (50), the globular heads are required for recognition of the majority of $\mathrm{C} 1 \mathrm{q}$ binding patterns including $\mathrm{C}$ reactive protein, pentraxins, LPS, apoptotic cells, DNA, amyloid$\beta$ fibrils, DC-SIGN, gC1qR, calreticulin, the Frizzled receptors, and the macrophage receptor SIGN-R1 (5, 6, 51-54). While the interactions with $\operatorname{IgG}$ and $\operatorname{IgM}$ are well characterized, much less is known about the molecular surfaces of $\mathrm{gClq}$ involved in recognition of non-immunoglobulin ligands (5557). We propose to use $\mathrm{C} 1 \mathrm{qNb} 75$ as a molecular tool to help decipher interactions between $\mathrm{Clq}$ and its ligands. Due to their small size, competition experiments with Nbs are likely to give rise to less long-range steric hindrance as compared to larger competitors, e.g., a conventional IgG or its Fab fragment. For this reason, Nbs offer a more accurate tool for mapping areas of interaction in such competition experiments. We envision C1qNb75 could be especially useful to study the involvement of $\mathrm{C} 1 \mathrm{q}$ in synaptic pruning and in neurodegenerative diseases like Alzheimer's disease (AD) and glaucoma, where the molecular structures recognized by $\mathrm{Clq}$ are still largely unknown as discussed below.

$\mathrm{C} 1 \mathrm{q}$ as well as other components of the $\mathrm{CP}$ are critical in the developing brain, and mice deficient in $\mathrm{C} 1 \mathrm{q}, \mathrm{C} 4, \mathrm{C} 3$, or CR3 have defects in synaptic connectivity (58). During development, binding and activation of $\mathrm{C} 1 \mathrm{q}$ on less active synapses leads to deposition of C3 degradation products that are recognized by CR3-expressing microglia which phagocytize the opsonized presynaptic terminals (59-61). However, the same pathway that ensures correct development by pruning excess synapses, seems to be involved in neurodegenerative conditions like AD (62). C1q and C3 are upregulated in AD mouse models and deposited complement components have been found in $\mathrm{AD}$ patients (63-66). In $\mathrm{AD}, \mathrm{C1q}$ binds to vulnerable synapses and activates the CP. This leads to $\mathrm{C} 3$ deposition on synapses which are phagocytosed by CR3-bearing microglia. C1 inhibition by antibodies or $\mathrm{C} 1 \mathrm{q} \mathrm{KO}$ prevents synapse loss following injection of oligomeric amyloid- $\beta$ (62). Similarly, C3 and CR3 KO rescues synapse loss in mice challenged with oligomeric amyloid- $\beta$ (62). It is not known whether $\mathrm{C} 1 \mathrm{q}$ binds directly to amyloid- $\beta$ in these models or the presence of amyloid- $\beta$ exposes other patterns on the synapse that are recognized by C1q. Likewise, little is known about the patterns bound by $\mathrm{Clq}$ during synaptic pruning. Thus, whether $\mathrm{C} 1 \mathrm{qNb} 75$ blocks binding of $\mathrm{C} 1 \mathrm{q}$ to the molecular structures exposed during development and/or in neurodegenerative diseases, like $\mathrm{AD}$, remains to be determined.

With respect to in vitro applications, $\mathrm{C} 1 \mathrm{qNb} 75$ may become a valuable tool for both functional studies and diagnostics. Due to the very high affinity of immobilized $\mathrm{C} 1 \mathrm{qNb} 75$ for $\mathrm{C} 1 \mathrm{q}$, the $\mathrm{Nb}$ appears suited for capture and quantitation of $\mathrm{Clq}$ in biological samples like serum and cerebrospinal fluid. Our experiments also provide evidence for its application in flow cytometry studies to investigate competition with cell bound $\mathrm{C} 1 \mathrm{q}$ binders. Finally, C1qNb75 specifically blocks the CP in functional assays and may thus allow investigators to unravel the specific contributions to complement activation from the CP and LP without depending on protein depletion or genetic knockouts.

In conclusion, we present a potent and high affinity inhibitor of the classical pathway of complement, that is based on the small and versatile $\mathrm{Nb}$ scaffold, and define its mode of inhibition through a combination of functional assays and structural biology. C1qNb75 stands out as a powerful tool for investigating CP-mediated complement activation in different contexts, which could possibly help determine binding modes on activators for which the interacting regions on $\mathrm{gClq}$ are unknown. We further suggest possible applications of $\mathrm{C} 1 \mathrm{qNb} 75$ as a diagnostic tool, and as a molecule that will efficiently inhibit $\mathrm{Clq}$ in vivo under conditions of excessive antibody-mediated CP activation.

\section{MATERIALS AND METHODS}

\section{Purification of Human C1q}

$\mathrm{C} 1 \mathrm{q}$ was purified from human outdated plasma using a procedure adapted from (67). Three bags of plasma were thawed at $4^{\circ} \mathrm{C}$ overnight to allow clotting, $5 \mathrm{mM}$ EDTA was added to the plasma and the precipitate was collected at $6,000 \mathrm{~g}$ for $30 \mathrm{~min}$. The supernatant was gaze filtered prior to $2 \mathrm{~h}$ incubation at room temperature (RT) with $100 \mathrm{~mL}$ Bio-Rex $70^{\mathrm{TM}}$ beads (Bio-Rad) equilibrated in $50 \mathrm{mM}$ Na2HPO4, $82 \mathrm{mM} \mathrm{NaCl}, 2 \mathrm{mM}$ EDTA pH 7.4 (buffer A). The beads were washed extensively with buffer A and packed on a XK16 (GE Healthcare) column. The column was washed with buffer A until baseline and eluted with a $300 \mathrm{~mL}$ linear gradient from 82 to $300 \mathrm{mM} \mathrm{NaCl}$. The fractions containing $\mathrm{C} 1 \mathrm{q}$ were pooled and a $1: 1 \mathrm{v} / \mathrm{v}$ ratio of $66 \%$ saturated $\left(\mathrm{NH}_{4}\right)_{2} \mathrm{SO}_{4}$ solution was dripped into the sample while stirring at $4{ }^{\circ} \mathrm{C}$. After $15 \mathrm{~h}$, the precipitate was pelleted by centrifugation at $3,000 \times \mathrm{g}$ for $30 \mathrm{~min}$ and purified C1q was resuspended in $50 \mathrm{mM}$ Tris- $\mathrm{HCl}, 500 \mathrm{mM} \mathrm{NaCl} \mathrm{pH} 7.2$ (storage buffer) and dialyzed three times for at least $6 \mathrm{~h}$ at $4^{\circ} \mathrm{C}$ against $2.5 \mathrm{~L}$ of storage buffer before flash freezing at $-80^{\circ} \mathrm{C}$. 


\section{Selection of C1qNb75}

Immunization, library generation and selection was performed essentially as described in (34). A llama was immunized four times each with a $100 \mu \mathrm{g}$ mixture of purified $\mathrm{Clq}$ and gC1q, the latter generated by collagenase digestion of $\mathrm{Clq}$ (3). After 84 days blood was collected and peripheral blood mononuclear

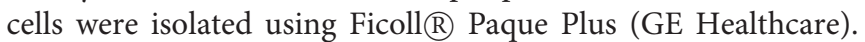
RNA was purified using a RNeasy® Plus Mini Kit (Qiagen) following the manufacture's protocol. cDNA was generated by reverse transcription with the Superscript $\AA$ III First-Strand kit (Invitrogen). Genes were amplified by PCR with VHH specific primers and cloned in to a phagemid vector containing E-tag peptide. Selection was performed in two consecutive rounds of selection. For the first round, $1 \mu \mathrm{g}$ of $\mathrm{C} 1 \mathrm{q}$ in $100 \mu \mathrm{L}$ PBS was coated in one well of a Maxisorp 96-well plate at $4^{\circ} \mathrm{C}$ ON. Following, the well was added $300 \mu \mathrm{L}$ PBS containing $2 \%$ bovine serum albumin (BSA) and incubated at RT for $1 \mathrm{~h}$. Simultaneously, phages were blocked in $100 \mu \mathrm{L}$ PBS containing $2 \%$ BSA for $1 \mathrm{~h}$ at RT. The well was washed with $3 \times 300 \mu \mathrm{L}$ PBS containing $0.1 \%$ Tween-20 (PBS-T) and phages were added and incubated for $1 \mathrm{~h}$ at RT. The well was washed with 15 $\times 300 \mu \mathrm{L}$ PBS-T followed by $15 \times 300 \mu \mathrm{L}$ PBS and phages were eluted by addition of $100 \mu \mathrm{L} 0.2 \mathrm{M}$ glycine $\mathrm{pH}$ 2.2. Phages were neutralized by addition of $15 \mu \mathrm{L}$ Tris $\mathrm{pH} 9.1$ and used for infection of ER2738 cells. Cells were plated on 2xYT agar plates containing $100 \mu \mathrm{g} / \mathrm{mL}$ ampicillin and $2 \%$ glucose and incubated $\mathrm{ON}$ at $30^{\circ} \mathrm{C}$. The following day the cells were recovered in $2 \mathrm{xYT}$ media and used for generation of phage particles with VCSM13 helper phages. The second round of selection was performed essentially as the first round of selection but now using $0.1 \mu \mathrm{g}$ C1q. Following this round of selection, single colonies from $2 \mathrm{xYT}$ agar plates were inoculated into a 96-well plate containing $200 \mu \mathrm{L}$ LB media with $100 \mu \mathrm{g} / \mathrm{mL}$ ampicillin. The plate was incubated at $37^{\circ} \mathrm{C}$ for $8 \mathrm{~h}$, added IPTG to a final concentration of $1 \mathrm{mM}$ and incubated $\mathrm{ON}$ at $30^{\circ} \mathrm{C}$. The following day the plate was centrifuged for $10 \mathrm{~min}$ at $450 \mathrm{~g}$ and the supernatant was used in an ELISA as described (34). Phagemids from ELISA positive clones were isolated and sequenced.

\section{Expression and Purification of C1qNb75}

The gene encoding C1qNb75 was cloned into a pET22b+ vector and transformed into LOBSTR cells (68). Cells were grown in LB medium containing $100 \mu \mathrm{g} / \mathrm{mL}$ ampicillin and $0.2 \%$ glucose at $37^{\circ} \mathrm{C}$. At $\mathrm{OD} 600=0.6-0.9$ IPTG was added to a final concentration of $0.5 \mathrm{mM}$ and incubated at $20^{\circ} \mathrm{C} \mathrm{ON}$. Cells were harvested by centrifugation and resolubilized in PBS containing $500 \mathrm{mM} \mathrm{NaCl}$ and $20 \mathrm{mM}$ imidazole (wash buffer) $\mathrm{pH}$ 8.0. Cells were sonicated and centrifuged at $14,000 \mathrm{~g}$ for $30 \mathrm{~min}$. The supernatant was incubated with Ni-NTA agarose beads (Protino), washed with wash buffer and eluted with wash buffer containing $300 \mathrm{mM}$ imidazole $\mathrm{pH}$ 7.5. The protein was dialyzed against $50 \mathrm{mM}$ sodium acetate $\mathrm{pH} 5.5$ and loaded on a MonoS 5/10 column (GE Healthcare) equilibrated in $50 \mathrm{mM}$ sodium acetate $\mathrm{pH}$ 5.5. The protein was eluted with a gradient from 0 to $500 \mathrm{mM} \mathrm{NaCl}$ and analyzed by SDS-PAGE. Fractions containing C1qNb75 were concentrated and loaded on a Superdex75 10/300 column (GE Healthcare) equilibrated in $20 \mathrm{mM}$ HEPES-NaOH,
$150 \mathrm{mM} \mathrm{NaCl}, \mathrm{pH}$ 7.5. The final yield was approximately one mg/L LB media.

\section{Classical Pathway Deposition Assays}

Each well in a 96-well Maxisorp plate (Thermo, Catalog Nr. 446612) was coated with $100 \mu \mathrm{L}$ solution of heat aggregated IgG at $15 \mu \mathrm{g} / \mathrm{mL}$ in $50 \mathrm{mM}$ sodium carbonate ( $\mathrm{pH}$ 9.6) (AMPLIQON Laboratory Reagents) and incubated $\mathrm{ON}$ at $4{ }^{\circ} \mathrm{C}$. The wells were blocked by addition of $250 \mu \mathrm{L}$ TBS/Tw $(20 \mathrm{mM}$ Tris, $150 \mathrm{mM}$ $\mathrm{NaCl} \mathrm{pH} 7.4$ and $0.05 \%$ Tween-20) supplemented with $1 \mathrm{mg} / \mathrm{mL}$ human serum albumin (HSA) for $1 \mathrm{~h}$ at RT. The wells were washed three times with $300 \mu \mathrm{L} 20 \mathrm{mM}$ HEPES-NaOH, $150 \mathrm{mM}$ $\mathrm{NaCl}, \mathrm{pH}$ 7.5. Nanobodies were diluted in veronal buffer $(4.9 \mathrm{mM}$ barbital, $145 \mathrm{mM} \mathrm{NaCl}, 0.25 \mathrm{mM} \mathrm{CaCl}_{2}, 1.76 \mathrm{mM} \mathrm{MgCl}_{2} \mathrm{pH}$ 7.28-7.6) (LONZA, Catalog No. 12-624E) placed on ice and added NHS to a final concentration of $0.2 \%$. The diluted $\mathrm{Nb} / \mathrm{NHS}$ $(100 \mu \mathrm{L})$ mixture was transferred to IgG coated wells and incubated for $90 \mathrm{~min}$ at $37^{\circ} \mathrm{C}$ in a humidity chamber. The wells were subsequently washed three times with TBS/Tw (TBS with $0.1 \%(\mathrm{v} / \mathrm{v})$ Tween 20). Hundred microliter biotinylated rabbit anti-C3c antibody (Dako, A0062) or biotinylated rabbit anti-C4c antibody (Dako, Q0364) diluted to $0.5 \mu \mathrm{g} / \mathrm{mL}$ in TBS/Tw was added and the plates were incubated for $1 \mathrm{~h}$ at RT. The wells were washed three times in TBS/Tw and each well was added $100 \mu \mathrm{L}$ of $1 \mu \mathrm{g} / \mathrm{mL}$ europium-labeled streptavidin (PerkinElmer, Catalog No. 1244-360) diluted in TBS/Tw containing $25 \mu \mathrm{M}$ EDTA and incubated for $1 \mathrm{~h}$ at RT. The wells were washed three times in TBS/Tw and then $200 \mu \mathrm{L}$ enhancement buffer (AMPLIQON lab reagent, Catalog No. Q99800) was added to each well. Time-resolved fluorescence was subsequently measured using a VICTOR3 Multilabel Plate counter (PerkinElmer).

\section{Binding of C1q to Nanobodies}

Wells of Maxisorp plates were coated with $100 \mu \mathrm{L}$ solution of nanobody or with rabbit $\mathrm{F}\left(\mathrm{ab}^{\prime}\right)_{2}$ anti-human $\mathrm{Clq}$ (the $\mathrm{F}\left(\mathrm{ab}^{\prime}\right)_{2}$ was prepared by pepsin treatment of rabbit anti-C1q antibody (A136, Dako) at $10 \mu \mathrm{g} / \mathrm{mL}$ in PBS and incubated ON at $4{ }^{\circ} \mathrm{C}$. The wells were blocked by addition of $250 \mu \mathrm{L}$ TBS supplemented with $1 \mathrm{mg} / \mathrm{mL}$ HSA for $1 \mathrm{~h}$ at RT. The wells were washed three times with TBS/Tween. Serum or purified C1q were diluted in TBS/Tw/Ca (TBS/Tw containing $5 \mathrm{mM} \mathrm{CaCl}_{2}$ ) and $100 \mu \mathrm{L}$ added per well. Following incubation for $1 \mathrm{~h}$ the wells were washed three times with TBS/Tw and $100 \mu \mathrm{L}$ of biotinylated rabbit anti-C1q antibody (Dako A136, biotinylated by standard methods) diluted to $0.25 \mu \mathrm{g} / \mathrm{mL}$ in TBS/Tw and the plates were incubated for $1 \mathrm{~h}$ at RT. The wells were washed three times in TBS/Tw and each well the received $100 \mu \mathrm{L}$ of $1 \mu \mathrm{g} / \mathrm{mL}$ europium-labeled streptavidin diluted in TBS/Tw containing $25 \mu \mathrm{M}$ EDTA and incubated for $1 \mathrm{~h}$ at RT. The wells were washed three times in TBS/Tw and then $200 \mu \mathrm{L}$ enhancement buffer was added to each well and timeresolved fluorescence was measured using a VICTOR3 Multilabel Plate counter (PerkinElmer).

\section{Binding of $\mathrm{C} 1 \mathrm{q}$ to $\mathrm{IgG}$ in the Presence of C1qNb75}

Wells of Maxisorp plates were coated with $100 \mu \mathrm{L}$ of normal human IgG at $15 \mu \mathrm{g} / \mathrm{mL}$ in in $50 \mathrm{mM}$ sodium carbonate $(\mathrm{pH}$ 
9.6) and incubated $\mathrm{ON}$ at $4^{\circ} \mathrm{C}$. The wells were then blocked by addition of $250 \mu \mathrm{L}$ TBS supplemented with $1 \mathrm{mg} / \mathrm{mL}$ HSA for $1 \mathrm{~h}$ at RT. The wells were then washed three times with TBS/Tw. Purified C1q (final concentration $50 \mathrm{ng} / \mathrm{mL}$ ), diluted in $\mathrm{TBS} / \mathrm{Tw} / \mathrm{Ca}$, was mixed with nanobodies or with rabbit anti$\mathrm{C} 1 \mathrm{q}$ at several dilutions and $100 \mu \mathrm{L}$ added per well. Following incubation for $1 \mathrm{~h}$, the wells were washed three times with $\mathrm{TBS} / \mathrm{Tw}$ and then $100 \mu \mathrm{L}$ of biotinylated rabbit anti-C1q antibody diluted to $0.25 \mu \mathrm{g} / \mathrm{mL}$ in TBS/Tw were added, and the plates were incubated for $1 \mathrm{~h}$ at RT. The wells were washed three times in TBS/Tw and each well then received $100 \mu \mathrm{L}$ of $1 \mu \mathrm{g} / \mathrm{mL}$ europium-labeled streptavidin diluted in TBS/Tw containing $25 \mu \mathrm{M}$ EDTA and incubated for $1 \mathrm{~h}$ at RT. The wells were washed three times in TBS/Tw and then $200 \mu \mathrm{L}$ enhancement buffer was added to each well and time-resolved fluorescence was measured using a VICTOR3 Multilabel Plate counter (PerkinElmer).

\section{Assay for C5a in Serum}

Serum samples with nanobody at different concentrations were incubated at $37^{\circ} \mathrm{C}$ for $18 \mathrm{~h}$ to initiate autoactivation of complement fragments. The samples were subsequently diluted 1/15 and tested for C5a content. The concentration of complement fragment C5a was measured using an ELISA kit from Hycult Biotech (catalog number HK349) as described by the manufacturer. It uses incubation of samples in microtiter wells coated with a monoclonal antibody that recognizes a neoepitope on C5a. This is followed by detection of bound C5a with a biotinylated antibody and subsequently addition of enzymelabeled streptavidin and enzyme substrate.

\section{Bio-layer Interferometry (BLI) Affinity Measurement}

BLI experiments were performed on an Octet Red96 (ForteBio) at $30^{\circ} \mathrm{C}, 1,000 \mathrm{rpm}$. $\mathrm{C} 1 \mathrm{qNb} 75$ were immobilized on amine reactive second-generation (AR2G) biosensors at $20 \mu \mathrm{g} / \mathrm{mL}$ in $20 \mathrm{mM}$ sodium acetate, $100 \mathrm{mM} \mathrm{NaCl} \mathrm{pH} \mathrm{5.0.} \mathrm{The} \mathrm{sensors}$ were quenched with $1 \mathrm{M}$ ethanol amine and equilibrated in kinetics buffer (PBS supplemented with $1 \mathrm{mg} / \mathrm{mL}$ BSA and $0.05 \%$ Tween 20). Association and dissociation were monitored with gC1q concentrations ranging from 0.3 to $10.9 \mathrm{nM}$ and $\mathrm{Clq}$ concentrations ranging from 0.7 to $5.4 \mathrm{nM}$ in kinetics buffer. For $\mathrm{gC1q}$, the data were globally fitted with a 1:1 binding model using the Octet Data Analysis software.

\section{Binding of C1q to IgG on Pig Red Blood Cells in the Presence of C1qNb75}

Venous EDTA stabilized blood was sampled from pigs undergoing experimental surgery at the Institute of Clinical Medicine, Aarhus University, Denmark and fixed with glutaraldehyde as described (32). Antibody deficient serum (ADS) was excess material from clinical investigations of a person with antibody deficiency and the use was approved by The Danish Data Protection Agency (reference number 1-16-02-40-12/2007-58-0010) and the Ethics Committee in Central Denmark Region (reference number 1-10-72-127-12). Human IgG antibodies against terminal galactose-alpha-1,3galactose were affinity isolated from a normal human IgG pool as described (32). Primary incubation of cells, human antibody deficient serum, and antibody was performed in RPMI with HSA at $1 \mathrm{~g} / \mathrm{L}$ constituting total volumes of $20 \mu \mathrm{L}$. The tubes were placed in a $37^{\circ} \mathrm{C}$ water bath and incubated for $2 \mathrm{~h}$. Nanobodies or EDTA were added as stated. Red blood cells were then washed in PBS by centrifugation ( $200 \mathrm{~g}, 10 \mathrm{~min}$ ). Cells were resuspended in $20 \mu \mathrm{L}$ PBS containing HSA at $1 \mathrm{mg} / \mathrm{mL}$ and secondary antibody (stock solutions diluted 300-fold). Secondary antibodies were fluorescein-isothiocyanate (FITC)-labeled polyclonal rabbit $\mathrm{F}(\mathrm{ab}) 2$ anti-human IgG or biotinylated polyclonal rabbit antihuman C1q (both from Dako, Denmark). Secondary incubations were done in the dark at RT for $30 \mathrm{~min}$. RBCs were washed again in PBS/HSA and resuspended in $20 \mu \mathrm{L}$ Streptavidin APCeFluor780 (eBioscience/ThermoFisher Scientific, Waltham, MA) in PBS/HSA (v/v: 1/300). The cells were mixed and incubated in the dark at RT for 30 min. Finally, the cells were washed and resuspended in $100 \mu \mathrm{L}$ flow buffer (PBS, pH 7.4) and analyzed on a NovoCyte Quanteon (ACEA Biosciences, Inc., San Diego, CA). Median fluorescence intensity (MFI) of experiments were subtracted background fluorescence and expressed relative to the mean of a reference experiment as stated in the text. Background fluorescence was defined as $99.9 \%$ of the lowest MFI acquired in associated experiments (99.9\% was preferred over 100\% to allow use of geometrical means).

\section{Hemolysis Assay With IgG Coated Sheep Red Blood Cells}

Sheep red blood cells (sRBCs) in Alsever's solution (SSI, Denmark) were washed with BI buffer (Lonza veronal buffer containing $2 \mathrm{mM} \mathrm{CaCl} 2$ ) supplemented with $1 \mathrm{mg} / \mathrm{mL}$ gelatin and diluted to $6 \% \mathrm{v} / \mathrm{v}$. Lyophilized rabbit anti-sRBC stroma antibody (Sigma-Aldrich S1389) was reconstituted in $2 \mathrm{~mL}$ PBS and $50 \mu \mathrm{L}$ was added to $10 \mathrm{~mL}$ BI buffer. The antibody was mixed with $10 \mathrm{~mL} 6 \%$ sRBCs in BI buffer and incubated at RT for $30 \mathrm{~min}$. Cells were pelleted by centrifugation at 1,000 $\mathrm{g}$ for $6 \mathrm{~min}$ and the supernatant was removed. The cells were resuspended in $10 \mathrm{~mL}$ BI buffer. For each Nb concentration, $15 \mu \mathrm{L}$ of NHS was added to $185 \mu \mathrm{L} \mathrm{Nb}$ diluted in BI buffer and incubated for $15 \mathrm{~min}$ on ice. Sixty microliter from each reaction were then transferred to a $\mathrm{V}$-shaped 96-well plate in triplicates and placed on wet ice before $30 \mu \mathrm{L} 6 \%$ sRBCs were added. The plate was vortexed and incubated at $37^{\circ} \mathrm{C}$ in a humid chamber at $250 \mathrm{rpm}$. After $30 \mathrm{~min}$, $100 \mu \mathrm{L}$ stop solution $(0.9 \% \mathrm{NaCl}, 5 \mathrm{mM}$ EDTA $)$ was added to each well. The plate was vortexed and subsequently centrifuged at $450 \mathrm{~g}$ for $6 \mathrm{~min}$. Fifty microliter of sample was transferred to a flat-bottom microtiter plate containing $50 \mu \mathrm{L}$ stop solution and vortexed. The absorbance was measured at $405 \mathrm{~nm}$ using a VICTOR3 Multilabel Plate counter. \% lysis was calculated with the formula: $\%$ lysis $=\left(\left(\mathrm{OD} 405_{\text {test }}-\mathrm{OD} 405_{\text {blank }}\right) /\left(\mathrm{OD} 405_{\text {totallysis }}{ }^{-}\right.\right.$ OD $\left.\left.405_{\text {blank }}\right)\right)^{*} 100$, with OD405 blank being incubation with buffer and OD405 $5_{\text {totallysis }}$ incubation with water.

\section{Hemolysis Assay With IgM Coated Sheep Red Blood Cells}

sRBCs coated with rabbit anti-sheep erythrocyte IgM (Complement technology, catalog \#B200) were pelleted by 
centrifugation at $1,000 \mathrm{~g}$. Supernatant was removed and sRBCs were resuspended in veronal buffer (Lonza) containing $4.9 \mathrm{mM}$ barbital, $145 \mathrm{mM} \mathrm{NaCl}, 0.25 \mathrm{mM} \mathrm{CaCl}_{2}, 1.76 \mathrm{mM} \mathrm{MgCl}_{2} \mathrm{pH}$ 7.28-7.6 and supplemented with $0.1 \%$ gelatin (assay buffer) to $5 \times 10^{8}$ cells $/ \mathrm{mL}$. For each reaction $20 \mu \mathrm{L} \mathrm{Nb}$ was mixed with $53 \mu \mathrm{L}$ assay buffer and $100 \mu \mathrm{L}$ NHS diluted 1/50 in assay buffer. After 15 min incubation on ice, $27 \mu \mathrm{L}$ sRBCs was added and $90 \mu \mathrm{L}$ from each reaction was pipetted into a V-shaped 96-well plate in duplicates. The plate was incubated in a water bath for $60 \mathrm{~min}$ at $37^{\circ} \mathrm{C}$ with shaking at $1,400 \mathrm{rpm}$ every $10 \mathrm{~min}$. After $60 \mathrm{~min}$, the plate was centrifuged at $1,000 \mathrm{~g}$ for $3 \mathrm{~min}$ and $80 \mu \mathrm{L}$ form each well was pipetted into a flat bottom 96-well plate and absorbance was measured at $541 \mathrm{~nm}$. \% lysis was calculated by using the following formula: \% lysis $=\left(\left(\right.\right.$ OD $541_{\text {test }}-$ OD $\left.541_{\text {blank }}\right) /\left(\right.$ OD $541_{\text {totallysis }}-$ OD $\left.\left.541_{\text {blank }}\right)\right) * 100$, with OD541 blank being sRBCs incubated with buffer and OD541 $1_{\text {totallysis }}$ being sRBCs incubated with water. IC50 was calculated with GraphPad by fitting the data with a variable slope model.

\section{Generation of Stable Cell Line and Purification of Human gC1q}

A transfected HEK293 stable cell line for expression of the single-chain form of gC1q (69) with a C-terminal His6 tag was generated as follows. Prior to transfection, HEK 293F cells were split to $0.5 \times 10^{6}$ cells $/ \mathrm{mL}$ in serum-free FreeStyle 293 medium (Gibco) and incubated $\mathrm{ON}$ at $37^{\circ} \mathrm{C}$ at $8 \% \mathrm{CO}_{2}$ with shaking. The following day, cells were collected by centrifugation and resuspended in fresh medium to give $2 \times 10^{6}$ cells $/ \mathrm{mL}$. The cells were incubated for $1 \mathrm{~h}$ with shaking and transfected using $1 \mu \mathrm{g}$ DNA (gC1q in pcDNA3.1) per $1 \mathrm{~mL}$ final culture volume and a $2: 1(w: w)$ ratio of polyethylenimine ( $25 \mathrm{kDa}$; Polysciences) to DNA. After $4 \mathrm{~h}$, the cells were diluted to $10^{6}$ cells $/ \mathrm{mL}$ in FreeStyle 293 medium and incubated $\mathrm{ON}$ at $37^{\circ} \mathrm{C}$ at $8 \% \mathrm{CO}_{2}$ with shaking. The next day, $0.25 \times 10^{6}$ viable cells from each of the transfected cell cultures were transferred to 6-well plates containing FreeStyle 293 medium supplemented with 10\% $(v / v)$ fetal bovine serum (FBS) and incubated statically $\mathrm{ON}$ at $37^{\circ} \mathrm{C}$ at $8 \% \mathrm{CO}_{2}$ to allow the cells to adhere. Selection pressure was applied by the addition of fresh medium containing $10 \%$ FBS and 200-300 $\mu \mathrm{g} / \mathrm{mL}$ Geneticin (Gibco). The medium was changed every 2-3 days to remove dying cells and selection pressure was maintained for 11-18 days until foci could be identified. Single colonies were picked to a 24 -well plate and left to proliferate in FreeStyle 293 medium supplemented with FBS and Geneticin, before being transferred to 6-well plates and adapted to $0.1 \%$ FBS. Finally, the cells were resuspended in $10 \mathrm{~mL}$ FreeStyle 293 medium supplemented with $250 \mu \mathrm{g} / \mathrm{mL}$ Geneticin and transferred into $125 \mathrm{~mL}$ flasks. The cells were cultured as recommended by the manufacturer until a cell viability of $>90 \%$ was achieved. A western blot was performed on $20 \mu \mathrm{L}$ media to identify clones with high gC1q expression. The western blot was performed using THE ${ }^{\mathrm{TM}}$ His-Tag Antibody, (Genscript) (diluted 1:3,000 in low fat milk) and Goat anti-mouse IgG HRP (Thermo Fisher Scientific) (diluted 1:15,000 in PBS-T). Four clones with high gC1q expression were selected and used for small scale expression and pulldown experiment using Ni Excel beads (GE healthcare). The best clone yielded $\sim 2-4 \mathrm{mg}$ protein/L culture.
For large-scale expression, gC1q expressing cells were grown in FreeStyle 293 media for 7 days at $37^{\circ} \mathrm{C}, 150 \mathrm{rpm}$ and $8 \% \mathrm{CO}_{2}$. Cells were harvested by centrifugation and $\mathrm{gClq}$ was purified from culture media adjusted to $\mathrm{pH} 8.0$ using a $5 \mathrm{~mL}$ Histrap excel column (GE Healthcare). The column was washed to baseline with PBS containing $500 \mathrm{mM} \mathrm{NaCl}$ and $10 \mathrm{mM}$ Imidazole $\mathrm{pH}$ 8.0. The protein was eluted with $\mathrm{PBS}$ containing $500 \mathrm{mM} \mathrm{NaCl}$ and $400 \mathrm{mM}$ Imidazole $\mathrm{pH} 8.0$ and analyzed by SDS-PAGE. Fractions containing gC1q were concentered and loaded on a Superdex 200 Increase 10/300 column (GE Healthcare) in $20 \mathrm{mM}$ HEPES-NaOH, 150 mM NaCl, pH 7.5.

\section{Crystallization of hC1qGH-C1qNb75 Complex}

For complex formation gC1q was mixed with molar excess of $\mathrm{C} 1 \mathrm{qNb} 75$ and purified by size exclusion chromatography in $20 \mathrm{mM}$ HEPES-NaOH, $150 \mathrm{mM} \mathrm{NaCl}, \mathrm{pH} 7.5$ using a BioRad ENrich SEC 70 10/300 column. Complex containing fractions were pooled and concentrated to $8 \mathrm{mg} / \mathrm{mL}$. The complex was crystallized at $19^{\circ} \mathrm{C}$ by vapor diffusion against a reservoir containing $0.2 \mathrm{M}$ ammonium acetate, $0.1 \mathrm{M}$ BISTris $\mathrm{pH} 5.5,25 \% \mathrm{w} / \mathrm{v}$ PEG 3350 after mixing protein and reservoir in a 1:1 ratio. Crystals were cryoprotected in $0.1 \mathrm{M}$ BIS-Tris $\mathrm{pH} 5.5,37 \% \mathrm{w} / \mathrm{v}$ PEG 3350 and cryocooled in liquid nitrogen.

\section{Data Collection and Structure Determination}

Diffraction data were collected to $2.19 \AA$ at the EMBL P14 beam line, PETRA III. Diffraction data from a single crystal were processed with XDS (70). The structure was determined by molecular replacement using Phaser (71) taking advantage of the single chain $\mathrm{gClq}$ structure (PDB ID: $5 \mathrm{HKJ}$ ) and a nanobody (PDB ID: $5 \mathrm{NLW}$ ) as search models. In an iterative manner, the structure was rebuilt in COOT (72) and refined using phenix.refine (73).

\section{C1-IgM-C4b Model Building}

The C1-IgM model was built in the deposited cryo-ET 3D reconstruction (EMDB-4878) (17) using Pymol version 2.3.0. The Fc hexamer was derived from the crystal packing of PDB entry $1 \mathrm{HZH}(74)$. Next, the $6 \mathrm{FCZ}$ entry containing the $\mathrm{gClq}$ and the IgG-Fc was superimposed on each $\mathrm{Fc}$ in the $1 \mathrm{HZH}$ hexamer. For construction of the hexameric IgM-C1 model, the 6FCZ hexamer was manually docked into EMDB-4878 density. The gC1q's were translated outwards to fit the density without rotation, implying that the gC1q's arrangement is wider in the IgM bound $\mathrm{C} 1$ complex (17). To model the two paired $\mathrm{C} \mu 3$ domains, the corresponding $\mathrm{C} \varepsilon 3$ dimer from the structure of IgE Fc [PDB entry 2WQR, (75)] was docked into the density. The model was completed by placing at each docked IgE C 33 domain an omalizumab Fab from PDB entry 2XA8 (76). The structure of MASP-2 CCP1-CCP2-SP domains in complex with C4b (PDB: 4FXG) was placed inside the density and the C345c domain was separated from the rest of $\mathrm{C} 4 \mathrm{~b}$ in order to improve the fitting while maintaining the contacts with MASP-2. Next, the MASP-2 domains were replaced by C1s (PDB: 5UBM) (77) and C1r CCP1-CCP2-SP domains (PDB: 2QY0) were fitted in 
the corresponding density (78). The tetramer formed by the $\mathrm{C} 1 \mathrm{r}$ and C1s CUB1-EGF-CUB2 domains (PDB: 6F1C) (79) was fitted in the core by separating the two heterodimers and applying a translation, while the C1s CUB2 domain was released from the structure and fitted separately into the density. The C1q collagen stems generated as in (35) but with one additional interruption in the collagen fold at residues A88, B93, C92, were subsequently added in the density. A list of the PDB files used is provided in Table S2.

\section{DATA AVAILABILITY STATEMENT}

Diffraction data and the atomic model are deposited at the protein data bank PDBe under the entry $6 \mathrm{Z} 6 \mathrm{~V}$.

\section{AUTHOR CONTRIBUTIONS}

NL, DP, HG, AZ, JB, and AH generated C1qNb75, expressed and purified proteins, and determined the structure or conducted functional assays. ST and GA supervised research. NL and GA

\section{REFERENCES}

1. Bajic G, Degn SE, Thiel S, Andersen GR. Complement activation, regulation, and molecular basis for complement-related diseases. EMBO J. (2015) 34:2735-57. doi: 10.15252/embj.201591881

2. Reid KB, Porter RR. Subunit composition and structure of subcomponent C1q of the first component of human complement. Biochem J. (1976) 155:19-23. doi: 10.1042/bj1550019

3. Gaboriaud C, Juanhuix J, Gruez A, Lacroix M, Darnault C, Pignol D, et al. The crystal structure of the globular head of complement protein C1q provides a basis for its versatile recognition properties. J Biol Chem. (2003) 278:46974-82. doi: 10.1074/jbc.M307764200

4. Shelton E, Yonemasu K, Stroud RM. Ultrastructure of the human complement component, $\mathrm{Clq}$ (negative staining-glutamine synthetase-biologically active Clq). Proc Natl Acad Sci USA. (1972) 69:65-8. doi: 10.1073/pnas.69.1.65

5. Thielens NM, Tedesco F, Bohlson SS, Gaboriaud C, Tenner AJ. C1q: a fresh look upon an old molecule. Mol Immunol. (2017) 89:73-83. doi: 10.1016/j.molimm.2017.05.025

6. McGrath FD, Brouwer MC, Arlaud GJ, Daha MR, Hack CE, Roos A. Evidence that complement protein $\mathrm{Clq}$ interacts with C-reactive protein through its globular head region. J Immunol. (2006) 176:2950-7. doi: 10.4049/jimmunol.176.5.2950

7. Hughes-Jones NC, Gardner B. Reaction between the isolated globular subunits of the complement component $\mathrm{C} 1 \mathrm{q}$ and IgG-complexes. Mol Immunol. (1979) 16:697-701. doi: 10.1016/0161-5890(79)90010-5

8. Diebolder CA, Beurskens FJ, de Jong RN, Koning RI, Strumane K, Lindorfer MA, et al. Complement is activated by IgG hexamers assembled at the cell surface. Science. (2014) 343:1260-3. doi: 10.1126/science.1248943

9. Ugurlar D, Howes SC, de Kreuk B-J, Koning RI, de Jong RN, Beurskens FJ, et al. Structures of C1-IgG1 provide insights into how danger pattern recognition activates complement. Science. (2018) 359:794-97. doi: $10.1126 /$ science.aao4988

10. Duncan AR, Winter G. The binding site for C1q on IgG. Nature. (1988) 332:738-40. doi: 10.1038/332738a0

11. Idusogie EE, Wong PY, Presta LG, Gazzano-Santoro H, Totpal K, Ultsch M, et al. Engineered antibodies with increased activity to recruit complement. $J$ Immunol. (2001) 166:2571-5. doi: 10.4049/jimmunol.166.4.2571

12. Kishore U, Ghai R, Greenhough TJ, Shrive AK, Bonifati DM, Gadjeva MG, et al. Structural and functional anatomy of the globular domain of complement protein C1q. Immunol Lett. (2004) 95:113-28. doi: 10.1016/j.imlet.2004.06.015 wrote the manuscript with inputs from all authors. All authors contributed to the article and approved the submitted version.

\section{FUNDING}

This work was supported by the Lundbeck Foundation (BRAINSTRUC, R155-2015-2666) and R192-2015-726 and the Aarhus University Science and Technology Ph.D School GSST.

\section{ACKNOWLEDGMENTS}

The authors would like to acknowledge the beamline staff at EMBL Hamburg for help with data collection and Karen Margrethe Nielsen for excellent technical support.

\section{SUPPLEMENTARY MATERIAL}

The Supplementary Material for this article can be found online at: https://www.frontiersin.org/articles/10.3389/fimmu. 2020.01504/full\#supplementary-material
13. Kojouharova MS, Gadjeva MG, Tsacheva IG, Zlatarova A, Roumenina LT, Tchorbadjieva MI, et al. Mutational analyses of the recombinant globular regions of human $\mathrm{C} 1 \mathrm{q} \mathrm{A}, \mathrm{B}$, and $\mathrm{C}$ chains suggest an essential role for arginine and histidine residues in the C1q-IgG interaction. J Immunol. (2004) 172:4351-8. doi: 10.4049/jimmunol.172.7.4351

14. Roumenina LT, Ruseva MM, Zlatarova A, Ghai R, Kolev M, Olova N, et al. Interaction of $\mathrm{Clq}$ with IgG1, C-reactive protein and pentraxin 3: mutational studies using recombinant globular head modules of human C1q A, B, C chains. Biochemistry. (2006) 45:4093-104. doi: 10.1021/bi052646f

15. Moore GL, Chen H, Karki S, Lazar GA. Engineered Fc variant antibodies with enhanced ability to recruit complement and mediate effector functions. MAbs. (2010) 2:181-9. doi: 10.4161/mabs.2.2.11158

16. Arya S, Chen F, Spycher S, Isenman DE, Shulman MJ, Painter RH. Mapping of amino acid residues in the $\mathrm{C}$ mu 3 domain of mouse IgM important in macromolecular assembly and complement-dependent cytolysis. J Immunol. (1994) 152:1206-12.

17. Sharp TH, Boyle AL, Diebolder CA, Kros A, Koster AJ, Gros P. Insights into IgM-mediated complement activation based on in situ structures of IgM-C1-C4b. Proc Natl Acad Sci USA. (2019) 116:11900-905. doi: 10.1073/pnas.1901841116

18. Bally I, Inforzato A, Dalonneau F, Stravalaci M, Bottazzi B, Gaboriaud C, et al. Interaction of $\mathrm{Clq}$ with pentraxin 3 and $\operatorname{IgM}$ revisited: mutational studies with recombinant C1q variants. Front Immunol. (2019) 10:461. doi: 10.3389/fimmu.2019.00461

19. Zlatarova AS, Rouseva M, Roumenina LT, Gadjeva M, Kolev M, Dobrev I, et al. Existence of different but overlapping IgG- and IgM-binding sites on the globular domain of human C1q. Biochemistry. (2006) 45:9979-88. doi: $10.1021 /$ bi060539v

20. Thurman JM, Panzer SE, Le Quintrec M. The role of complement in antibody mediated transplant rejection. Mol Immunol. (2019) 112:240-6. doi: 10.1016/j.molimm.2019.06.002

21. Asgari N, Khorooshi R, Lillevang ST, Owens T. Complement-dependent pathogenicity of brain-specific antibodies in cerebrospinal fluid. $J$ Neuroimmunol. (2013) 254:76-82. doi: 10.1016/j.jneuroim.2012.09.010

22. Jarius S, Wildemann B. AQP4 antibodies in neuromyelitis optica: diagnostic and pathogenetic relevance. Nat Rev Neurol. (2010) 6:383-92. doi: 10.1038/nrneurol.2010.72

23. Engel AG, Lambert EH, Howard FM. Immune complexes (IgG and C3) at the motor end-plate in myasthenia gravis: ultrastructural and light microscopic localization and electrophysiologic correlations. Mayo Clin Proc. (1977) 52:267-80. 
24. Howard JF Jr. Myasthenia gravis: the role of complement at the neuromuscular junction. Ann N Y Acad Sci. (2018) 1412:113-28. doi: $10.1111 /$ nyas. 13522

25. Berentsen S. Cold agglutinin disease. Hematology Am Soc Hematol Educ Program. (2016) 2016:226-31. doi: 10.1182/asheducation-2016.1.226

26. Sabater L, Giralt A, Boronat A, Hankiewicz K, Blanco Y, Llufriu S, et al. Cytotoxic effect of neuromyelitis optica antibody (NMO-IgG) to astrocytes: an in vitro study. J Neuroimmunol. (2009) 215:31-5. doi: 10.1016/j.jneuroim.2009.07.014

27. Shi J, Rose EL, Singh A, Hussain S, Stagliano NE, Parry GC, et al. TNT003, an inhibitor of the serine protease C1s, prevents complement activation induced by cold agglutinins. Blood. (2014) 123:4015-22. doi: 10.1182/blood-2014-02-556027

28. Jaffe CJ, Atkinson JP, Frank MM. The role of complement in the clearance of cold agglutinin-sensitized erythrocytes in man. J Clin Invest. (1976) 58:942-9. doi: $10.1172 /$ JCI108547

29. Jager U, D'Sa S, Schorgenhofer C, Bartko J, Derhaschnig U, Sillaber C, et al. Inhibition of complement C1s improves severe hemolytic anemia in cold agglutinin disease: a first-in-human trial. Blood. (2019) 133:893-901. doi: 10.1182/blood-2018-06-856930

30. Mastellos DC, Ricklin D, Lambris JD. Clinical promise of next-generation complement therapeutics. Nat Rev Drug Discov. (2019) 18:707-29. doi: 10.1038/s41573-019-0031-6

31. Galili U, Clark MR, Shohet SB, Buehler J, Macher BA. Evolutionary relationship between the natural anti-Gal antibody and the Gal alpha 1--3Gal epitope in primates. Proc Natl Acad Sci USA. (1987) 84:1369-73. doi: 10.1073/pnas.84.5.1369

32. Bernth Jensen JM, Petersen MS, Ellerman-Eriksen S, Moller BK, Jensenius JC, Sorensen UBS, et al. Abundant human anti-Galalpha3Gal antibodies display broad pathogen reactivity. Sci Rep. (2020) 10:4611. doi: 10.1038/s41598-020-61632-9

33. Krissinel E, Henrick K. Inference of macromolecular assemblies from crystalline state. J Mol Biol. (2007) 372:774-97. doi: 10.1016/j.jmb.2007.05.022

34. Jensen RK, Pihl R, Gadeberg TAF, Jensen JK, Andersen KR, Thiel S, et al. A potent complement factor $\mathrm{C} 3$-specific nanobody inhibiting multiple functions in the alternative pathway of human and murine complement. J Biol Chem. (2018) 293:6269-81. doi: 10.1074/jbc.RA117.001179

35. Mortensen SA, Sander B, Jensen RK, Pedersen JS, Golas MM, Jensenius JC, et al. Structure and activation of $\mathrm{C} 1$, the complex initiating the classical pathway of the complement cascade. Proc Natl Acad Sci USA. (2017) 114:98691. doi: 10.1073/pnas.1616998114

36. Gaboriaud C, Ling WL, Thielens NM, Bally I, Rossi V. Deciphering the fine details of $\mathrm{cl}$ assembly and activation mechanisms: "mission impossible"? Front Immunol. (2014) 5:565. doi: 10.3389/fimmu.2014.00565

37. Kojouharova M, Reid K, Gadjeva M. New insights into the molecular mechanisms of classical complement activation. Mol Immunol. (2010) 47:2154-60. doi: 10.1016/j.molimm.2010.05.011

38. Idusogie EE, Presta LG, Gazzano-Santoro H, Totpal K, Wong PY, Ultsch $\mathrm{M}$, et al. Mapping of the $\mathrm{Clq}$ binding site on rituxan, a chimeric antibody with a human IgG1 Fc. J Immunol. (2000) 164:4178-84. doi: 10.4049/jimmunol.164.8.4178

39. Dempsey PW, Allison ME, Akkaraju S, Goodnow CC, Fearon DT. C3d of complement as a molecular adjuvant: bridging innate and acquired immunity. Science. (1996) 271:348-50. doi: 10.1126/science.271.5247.348

40. Carroll MC, Isenman DE. Regulation of humoral immunity by complement. Immunity. (2012) 37:199-207. doi: 10.1016/j.immuni.2012.08.002

41. Heesters BA, Chatterjee P, Kim YA, Gonzalez SF, Kuligowski MP, Kirchhausen T, et al. Endocytosis and recycling of immune complexes by follicular dendritic cells enhances $\mathrm{B}$ cell antigen binding and activation. Immunity. (2013) 38:1164-75. doi: 10.1016/j.immuni.2013. 02.023

42. Galvan MD, Greenlee-Wacker MC, Bohlson SS. C1q and phagocytosis: the perfect complement to a good meal. J Leukoc Biol. (2012) 92:489-97. doi: 10.1189/jlb.0212099

43. Scott D, Botto M. The paradoxical roles of $\mathrm{C} 1 \mathrm{q}$ and $\mathrm{C} 3$ in autoimmunity. Immunobiology. (2016) 221:719-25. doi: 10.1016/j.imbio.2015.05.001

44. Taylor PR, Carugati A, Fadok VA, Cook HT, Andrews M, Carroll MC, et al. A hierarchical role for classical pathway complement proteins in the clearance of apoptotic cells in vivo. J Exp Med. (2000) 192:359-66. doi: 10.1084/jem.192.3.359

45. Colonna L, Parry GC, Panicker S, Elkon KB. Uncoupling complement $\mathrm{C} 1 \mathrm{~s}$ activation from $\mathrm{Clq}$ binding in apoptotic cell phagocytosis and immunosuppressive capacity. Clin Immunol. (2016) 163:84-90. doi: 10.1016/j.clim.2015.12.017

46. Lansita JA, Mease KM, Qiu H, Yednock T, Sankaranarayanan S, Kramer S. Nonclinical development of ANX005: a humanized anti-C1q antibody for treatment of autoimmune and neurodegenerative diseases. Int J Toxicol. (2017) 36:449-62. doi: 10.1177/1091581817740873

47. Cruz JW, Damko E, Modi B, Tu N, Meagher K, Voronina V, et al. A novel bispecific antibody platform to direct complement activity for efficient lysis of target cells. Sci Rep. (2019) 9:12031. doi: 10.1038/s41598-019-48461-1

48. Danobeitia JS, Zens TJ, Chlebeck PJ, Zitur LJ, Reyes JA, Eerhart MJ, et al. Targeted donor complement blockade after brain-death prevents delayed graft function in a non-human primate model of kidney transplantation. Am J Transplant. (2020) 20:1513-1526. doi: 10.1111/ajt.15777

49. Castellano G, Melchiorre R, Loverre A, Ditonno P, Montinaro V, Rossini M, et al. Therapeutic targeting of classical and lectin pathways of complement protects from ischemia-reperfusion-induced renal damage. Am J Pathol. (2010) 176:1648-59. doi: 10.2353/ajpath.2010.090276

50. Yin C, Ackermann S, Ma Z, Mohanta SK, Zhang C, Li Y, et al. ApoE attenuates unresolvable inflammation by complex formation with activated C1q. Nat Med. (2019) 25:496-506. doi: 10.1038/s41591-018-0336-8

51. Prabagar MG, Do Y, Ryu S, Park JY, Choi HJ, Choi WS, et al. SIGN-R1, a C-type lectin, enhances apoptotic cell clearance through the complement deposition pathway by interacting with C1q in the spleen. Cell Death Differ. (2013) 20:535-45. doi: 10.1038/cdd.2012.160

52. Kang YS, Do Y, Lee HK, Park SH, Cheong C, Lynch RM, et al. A dominant complement fixation pathway for pneumococcal polysaccharides initiated by SIGN-R1 interacting with C1q. Cell. (2006) 125:47-58. doi: 10.1016/j.cell.2006.01.046

53. Lu J, Kishore U. C1 complex: an adaptable proteolytic module for complement and non-complement functions. Front Immunol. (2017) 8:592. doi: 10.3389/fimmu.2017.00592

54. Naito AT, Sumida T, Nomura S, Liu ML, Higo T, Nakagawa A, et al. Complement $\mathrm{C} 1 \mathrm{q}$ activates canonical Wnt signaling and promotes agingrelated phenotypes. Cell. (2012) 149:1298-313. doi: 10.1016/j.cell.2012.03.047

55. Roumenina L, Bureeva S, Kantardjiev A, Karlinsky D, Andia-Pravdivy JE, Sim $\mathrm{R}$, et al. Complement C1q-target proteins recognition is inhibited by electric moment effectors. J Mol Recogn. (2007) 20:405-15. doi: 10.1002/jmr.853

56. Garlatti V, Chouquet A, Lunardi T, Vivès R, Païdassi H, Lortat-Jacob H, et al. Cutting edge: $\mathrm{Clq}$ binds deoxyribose and heparan sulfate through neighboring sites of its recognition domain. J Immunol. (2010) 185:808-12. doi: 10.4049/jimmunol.1000184

57. Païdassi H, Tacnet-Delorme P, Garlatti V, Darnault C, Ghebrehiwet B, Gaboriaud C, et al. C1q binds phosphatidylserine and likely acts as a multiligand-bridging molecule in apoptotic cell recognition. J Immunol. (2008) 180:2329-38. doi: 10.4049/jimmunol.180.4.2329

58. Stephan AH, Barres BA, Stevens B. The complement system: an unexpected role in synaptic pruning during development and disease. Ann Rev Neurosci. (2012) 35:369-89. doi: 10.1146/annurev-neuro-061010-113810

59. Schafer DP, Lehrman EK, Kautzman AG, Koyama R, Mardinly AR, Yamasaki R, et al. Microglia sculpt postnatal neural circuits in an activity and complement-dependent manner. Neuron. (2012) 74:691-705. doi: 10.1016/j.neuron.2012.03.026

60. Stevens B, Allen NJ, Vazquez LE, Howell GR, Christopherson KS, Nouri N, et al. The classical complement cascade mediates CNS synapse elimination. Cell. (2007) 131:1164-78. doi: 10.1016/j.cell.2007.10.036

61. Lui H, Zhang J, Makinson SR, Cahill MK, Kelley KW, Huang HY, et al. Progranulin deficiency promotes circuit-specific synaptic pruning by microglia via complement activation. Cell. (2016) 165:921-35. doi: 10.1016/j.cell.2016.04.001

62. Hong S, Beja-Glasser VF, Nfonoyim BM, Frouin A, Li S, Ramakrishnan S, et al. Complement and microglia mediate early synapse loss in Alzheimer mouse models. Science. (2016) 352:712-6. doi: 10.1126/science.aad8373

63. Dejanovic B, Huntley MA, De Maziere A, Meilandt WJ, Wu T, Srinivasan $\mathrm{K}$, et al. Changes in the synaptic proteome in tauopathy and rescue of 
tau-induced synapse loss by C1q antibodies. Neuron. (2018) 100:1322-36.e7. doi: 10.1016/j.neuron.2018.10.014

64. Afagh A, Cummings BJ, Cribbs DH, Cotman CW, Tenner AJ. Localization and cell association of C1q in Alzheimer's disease brain. Exp Neurol. (1996) 138:22-32. doi: 10.1006/exnr.1996.0043

65. Yasojima K, McGeer EG, McGeer PL. Complement regulators C1 inhibitor and CD59 do not significantly inhibit complement activation in Alzheimer disease. Brain Res. (1999) 833:297-301. doi: 10.1016/S0006-8993(99) 01514-0

66. Zanjani H, Finch CE, Kemper C, Atkinson J, McKeel D, Morris JC, et al. Complement activation in very early Alzheimer disease. Alzheimer Dis Assoc Disord. (2005) 19:55-66. doi: 10.1097/01.wad.0000165506.60370.94

67. Tenner AJ, Lesavre PH, Cooper NR. Purification and radiolabeling of human Clq. J Immunol. (1981) 127:648-53.

68. Andersen KR, Leksa NC, Schwartz TU. Optimized E. coli expression strain LOBSTR eliminates common contaminants from His-tag purification. Proteins. (2013) 81:1857-61. doi: 10.1002/prot.24364

69. Moreau C, Bally I, Chouquet A, Bottazzi B, Ghebrehiwet B, Gaboriaud C, et al. Structural and functional characterization of a single-chain form of the recognition domain of complement protein C1q. Front Immunol. (2016) 7:79. doi: 10.3389/fimmu.2016.00079

70. Kabsch W. Integration, scaling, space-group assignment and postrefinement. Acta Crystallogr D Biol Crystallogr. (2010) 66:133-44. doi: $10.1107 /$ S0907444909047374

71. McCoy AJ, Grosse-Kunstleve RW, Adams PD, Winn MD, Storoni LC, Read RJ. Phaser crystallographic software. J Appl Crystallogr. (2007) 40:658-674. doi: $10.1107 / S 0021889807021206$

72. Emsley P, Lohkamp B, Scott WG, Cowtan K. Features and development of Coot. Acta Crystallogr D Biol Crystallogr. (2010) 66:486-501. doi: $10.1107 /$ S0907444910007493

73. Afonine PV, Grosse-Kunstleve RW, Echols N, Headd JJ, Moriarty NW, Mustyakimov $\mathrm{M}$, et al. Towards automated crystallographic structure refinement with phenix.refine. Acta Crystallogr D Biol Crystallogr. (2012) 68:352-67. doi: 10.1107/S0907444912001308

74. Saphire EO, P. Parren WHI, Pantophlet R, Zwick MB, Morris GM, Rudd PM, et al. Crystal structure of a neutralizing human IgG against HIV-1: a template for vaccine design. Science. (2001) 293:1155-59. doi: 10.1126/science. 1061692

75. Holdom MD, Davies AM, Nettleship JE, Bagby SC, Dhaliwal B, Girardi E, et al. Conformational changes in IgE contribute to its uniquely slow dissociation rate from receptor FceRI. Nat Struct Mol Biol. (2011) 18:571-6. doi: $10.1038 / \mathrm{nsmb} .2044$

76. Wright JD, Chu H-M, Huang C-H, Ma C, Wen Chang T, Lim C. Structural and physical basis for anti-IgE therapy. Sci Rep. (2015) 5:11581. doi: $10.1038 /$ srep 11581

77. Pang SS, Wijeyewickrema LC, Hor L, Tan S, Lameignere E, Conway EM, et al. The structural basis for complement inhibition by gigastasin, a protease inhibitor from the Giant Amazon leech. J Immunol. (2017) 199:3883-3891. doi: 10.4049/jimmunol.1700158

78. Kardos J, Harmat V, Palló A, Barabás O, Szilágyi K, Gráf L, et al. Revisiting the mechanism of the autoactivation of the complement protease $\mathrm{Clr}$ in the $\mathrm{C} 1$ complex: structure of the active catalytic region of C1r. Mol Immunol. (2008) 45:1752-60. doi: 10.1016/j.molimm.2007.09.031

79. Almitairi JOM, Venkatraman Girija U, Furze CM, Simpson-Gray X, Badakshi F, Marshall JE, et al. Structure of the C1r-C1s interaction of the C1 complex of complement activation. Proc Natl Acad Sci USA. (2018) 115:768-73. doi: $10.1073 /$ pnas. 1718709115

Conflict of Interest: NL, AZ, DP, ST, and GA are listed as inventors on a patent describing the use of C1qNb75.

The remaining authors declare that the research was conducted in the absence of any commercial or financial relationships that could be construed as a potential conflict of interest.

Copyright $\odot 2020$ Laursen, Pedersen, Gytz, Zarantonello, Bernth Jensen, Hansen, Thiel and Andersen. This is an open-access article distributed under the terms of the Creative Commons Attribution License (CC BY). The use, distribution or reproduction in other forums is permitted, provided the original author(s) and the copyright owner(s) are credited and that the original publication in this journal is cited, in accordance with accepted academic practice. No use, distribution or reproduction is permitted which does not comply with these terms. 